\title{
Magnetic mineralogy of Variscan granites from northern Portugal: an approach to their petrogenesis and metallogenic potential
}

\author{
$\begin{array}{lll}\text { C. } \text { Cruz }^{1,2} & \text { H. Sant'Ovaia } & \\ & & \text { F. Noronha } \\ & 1,2\end{array}$ \\ 'Departamento de Geociências Ambiente e Ordenamento do Território - Faculdade de Ciências, Universidade do Porto \\ Rua do Campo Alegre 687, Porto, Portugal. Cruz E-mail: claudiacruz@fc.up.pt \\ Sant'Ovaia E-mail: hsantov@fc.up.pt \\ ${ }^{2}$ Instituto de Ciências da Terra, Polo Porto \\ Rua do Campo Alegre 687, Porto, Portugal \\ Noronha E-mail: fmnoronh@fc.up.pt
}

\begin{abstract}
A B S T R A C T
Northern Portugal is characterized by the occurrence of numerous W hydrothermal deposits spatially associated with granites. The primary goal of this work is to establish a relationship between the magnetic behavior of the granites and the redox conditions during magma genesis, as this can influence the occurrence of mineralizations, namely of $\mathrm{W}$ (Mo). To this end, the magnetic mineralogy of the granites of the Lamas de Olo Pluton, a posttectonic pluton in northern Portugal, with associated W (Mo) occurrences was characterized and compared with the magnetic mineralogy of other post-tectonic Variscan plutons. This pluton is composed of different biotite granites: Lamas de Olo, Alto dos Cabeços and Barragem. To better characterize its magnetic behavior, different analytical techniques that complement previous magnetic susceptibility studies were performed. The magnetic mineralogy of Lamas de Olo Pluton was then compared with other post-tectonic Variscan plutons such as the Vila Pouca de Aguiar, Peneda-Gerês and Lavadores-Madalena plutons. The presence of magnetite in some of these granites is important because it points to melt-oxidized conditions not commonly found in Iberian Variscan granites. Our study shows that granite areas where magnetite and/or magnetite/ilmenite coexist are important targets for W (Mo) mineralizations. The results indicate that a few plutons have granites with a complex redox history which leads to the formation of magnetite and ilmenite.
\end{abstract}

KEYWORDS

Magnetic mineralogy. Variscan granites. Post- $D_{3}$ biotite granites. Central Iberian Zone. W-Mo mineralizations.

\section{INTRODUCTION}

The northern area of Portugal is characterized by large volumes of granitic intrusions related to Variscan orogeny (321-290Ma). Synorogenic granites represent the plutonic magmatism and, based on their geological, petrographic and geochemical characteristics, are divided into two main groups (e.g. Chappell and White, 1974; Dias et al., 2010; Ferreira et al., 1987; Noronha et al., 2006). The first group consists of two- mica peraluminous granites, which are dominantly syntectonic (syn- $\mathrm{D}_{3}: 321-312 \mathrm{Ma}$ ) and considered S-type granites, resulting from the crystallization of wet peraluminous magmas originated at a mesocrustal level. The second group consists of biotite granites considered to have been generated at deep crustal levels and corresponding to dry magmas. The age of their formation is either syn- $\mathrm{D}_{3}(321-312 \mathrm{Ma})$, late- $\mathrm{D}_{3}$ $(312-305 \mathrm{Ma})$, late- to post- $\mathrm{D}_{3}(c a .300 \mathrm{Ma})$, or post- $\mathrm{D}_{3}$ (299-290Ma) (Dias et al., 2010).

(C) C. Cruz, H. Sant'Ovaia, F. Noronha, 2020 CC BY-SA 
These two types of granites have distinctive wholerock oxygen isotope $\left(\delta^{18} \mathrm{O}\right)$ values. The highest $\delta^{18} \mathrm{O}$ values indicate a crustal origin, and the lowest values suggest a mantle contribution and/or source region dominated by mafic and meta-igneous rocks (Ellwood and Wenner, 1981; Ishihara, 1977). The $\delta^{18} \mathrm{O}$ mean values range between $10.65 \%$ and $12.90 \%$ for the two-mica granites and $9.75 \%$ and $12.84 \%$ or the biotite granites (Antunes et al., 2008; Cruz et al., 2016; Sant'Ovaia et al., 2013a, b; Teixeira et al., 2012).

The magnetic susceptibility $\left(\mathrm{K}_{m}\right)$ of granites is an important characteristic and it is mainly controlled by the presence of certain oxide minerals like magnetite and/or ilmenite as well as ferromagnesian silicates such as biotite.

The abundance of magnetite or ilmenite can be explained by different redox conditions in the magma chamber and different magma sources. The presence of magnetite or ilmenite as accessory minerals represents oxidized- or magnetite-type granites and reduced- or ilmenite-type granites, respectively (Ishihara, 1977). Magnetite granites are considered to have been generated at great depth (upper mantle and/or lower crust), whereas the ilmenite-series are considered to have originated at a shallower level (middle to lower continental crust) where small amounts of crustal carbon are present (Ellwood and Wenner, 1981; Ishihara, 1977; Sheppard, 1977). Relative abundances of magnetic minerals in granites can be measured in terms of magnetic susceptibility, with the magnetite-series having $\mathrm{K}_{m}>3.0 \cdot 10^{-3} \mathrm{SI}$ and ilmeniteseries, in general, with $\mathrm{K}_{m}$ around $10^{-6} \mathrm{SI}$ (or $\mu \mathrm{SI}$ ) (e.g. Ishihara, 1977; Takagi and Tsukimura, 1997).

In the Iberian Variscan belt, specifically in the Central Iberian Zone (CIZ), in Spain and Portugal, the magnetic behavior of numerous granites has been analyzed. The Spanish granites are mostly ilmenite-type and have been extensively analyzed by several authors, like Aranguren et al. (1996); Olivia-Urcia et al. (2012); Porquet et al. (2017); Román-Berdiel et al. (1995). These authors found $\mathrm{K}_{m}$ values between $22 \mu \mathrm{SI}$ and $467 \mu \mathrm{SI}$. Recent studies carried out by Villaseca et al. (2017) proved the existence of both ilmenite- and magnetite-type granites in the Spanish Central System. The magnetic susceptibility of these granites yielded $\mathrm{K}_{m} c a$. $15 \mu \mathrm{SI}$ to $180 \mu \mathrm{SI}$ for $\mathrm{S}-$ and I-type granites (ilmenite-type granites) and values between $500 \mu \mathrm{SI}$ and $1,400 \mu \mathrm{SI}$ for the leucogranites I-type granites (magnetite-type granites). Magnetic susceptibility studies in several Portuguese granites (Sant'Ovaia et al., 2014) yielded $\mathrm{K}_{m}$ mean values between $48 \mu \mathrm{SI}$ and $84 \mu \mathrm{SI}$ for two-mica granites corresponding to ilmenite-type granites and between $72 \mu \mathrm{SI}$ and $11,676 \mu \mathrm{SI}$ for biotite granites corresponding to ilmenite-type and/or magnetite-type granites.
Several metallogenic events are identified on the granite bodies: i) $\mathrm{Sn}-\mathrm{Li}$ pegmatites are essentially associated to syn- $\mathrm{D}_{3}$ with two-mica granites; ii) W (Sn) and $\mathrm{W}$ quartz-vein deposits occur in late- and late- to post- $\mathrm{D}_{3}$ biotite granites; and iii) W (Mo) deposits are related to post- $\mathrm{D}_{3}$ biotite sub-alkaline granites (e.g. Mateus and Noronha, 2010; Noronha, 2017; Thadeu, 1965).

The magnetic susceptibility $\left(\mathrm{K}_{m}\right)$ and $\delta^{18} \mathrm{O}$ data allow to establish a relationship between the granite type (ilmenite- or magnetite-type) and the associated mineralizations (Kumar, 2010; Takagi and Tsukimura, 1997). The occurrence of ore deposits associated with ilmenite-type and/or magnetite-type granites has been largely described, for example, in Indonesia (Maulana et al., 2013) and, in southern Korea and southwestern Japan (Ishihara et al., 1981) and, more recently, in Portugal (Cruz et al., 2016; Sant'Ovaia et al., 2014). In Sulawesi, Indonesia, the ilmenite-type granites outcrop in the southern zone of the island while the magnetite-type granites occur in the northern area. Both granites have associated ore mineralization. $\mathrm{Cu}-\mathrm{Au}-\mathrm{Mo}$ mineralizations are associated with magnetite-series granitic rocks, while $\mathrm{Sn}-\mathrm{W}$ mineralizations related to reduced ilmenite-type granites have not yet been reported (Maulana et al., 2013). Contrastingly, in southern Korea and southwestern Japan (Ishihara et al., 1981), W-Mo occurrences were described in areas with both ilmenite- and magnetite-type granites with no clear separation in the distribution of the two types of granites. In the Portuguese sector of the Central Iberian Zone, the Sn deposits are associated with S- and ilmenite-type granites and the $\mathrm{W}$-(Sn) mineralizations occur in veins that cut the I (peraluminous)- and ilmenitetype granites, both with high $\delta^{18} \mathrm{O}$ values, The $\mathrm{W}$ (Mo) occurrences are spatially related to I (peraluminous)- and magnetite-type granites (Cruz et al., 2016; Sant'Ovaia et al., 2012).

The study of magnetic mineralogy expands our knowledge of the relation between granites and their related mineralizations, since the redox conditions control the specific mineral occurrences. It is very important to understand the relationship between magnetic mineralogy and ore deposits considering the complexity of magma genesis.

The main goal of this work is to characterize the magnetic behavior of the Lamas de Olo Pluton (LOP) and compare it with the magnetic behavior of other post-tectonic Variscan biotite plutons (Peneda-Gerês Pluton (PGP), LavadoresMadalena Pluton (LMP) and Vila Pouca de Aguiar Pluton (VPAP). We aim at establishing a relationship between the magnetic behavior of the granites and the occurrence of different kinds of mineralizations. 


\section{GENERAL FRAMEWORK}

\section{The Iberian Variscan belt}

The Iberian Variscan belt was formed as a large curved segment of the European Variscan belt resulting from the Laurussia-Gondwana collision during Devonian to Carboniferous times (Franke, 1989; Kroner and Romer, 2013; Ribeiro et al., 1990). After the collision, during the late Paleozoic, the Pangea amalgamation leads to continuous rock deformation and the $\mathrm{C}$-shaped Cantabrian orocline was formed (e.g. Gutiérrez-Alonso et al., 2012; Weil et al., 2013). Other authors suggest a more complex scenario, with the existence of two oroclines, in S-shaped, the Cantabrian, and Central-Iberian (e.g. Pastor-Galán et al., 2012; Shaw et al., 2012).

The Iberian belt is subdivided into several geotectonic zones (Fig. 1): the Cantabrian Zone (CZ), the West Asturian Leonese Zone (WALZ), the CIZ, the Ossa Morena Zone
(OMZ) and the South Portuguese Zone (SPZ) (Julivert et al., 1974). Farias et al. (1987) identified allochthonous and parautochthonous units in the CIZ, which led them to consider another zone, the Galicia Trás-os-Montes Zone (GTMZ).

Three main ductile deformation phases have been documented in northern Portugal, namely $\mathrm{D}_{1}, \mathrm{D}_{2}$ and $\mathrm{D}_{3}$ (Noronha et al., 1981). In the CIZ, two main phases of deformation can be recognized in the autochthonous terrane: $\mathrm{D}_{1}$ (ca. 360-337Ma, e.g. Castiñeiras et al., 2008; Dallmeyer et al., 1997; Díez Fernández et al., 2016; Martínez Catalán et al., 2014; Pereira et al., 2018), and $\mathrm{D}_{3}$ (ca. 321-300Ma, e.g. Ferreira et al., 1987; Pereira et al., 2018). $\mathrm{D}_{1}$ produced isoclinal folds with a subvertical axial plane with a NW-SE strike and a well-marked axial plane schistosity $\left(\mathrm{S}_{1}\right)$, and $\mathrm{D}_{3}$ is characterized by wide folding of small amplitude on the subvertical axial plane and sub-horizontal NW-SE axis. Simultaneously with the $\mathrm{D}_{3}$, vertical ductile shear zones were developed in lower structural levels. In the upper

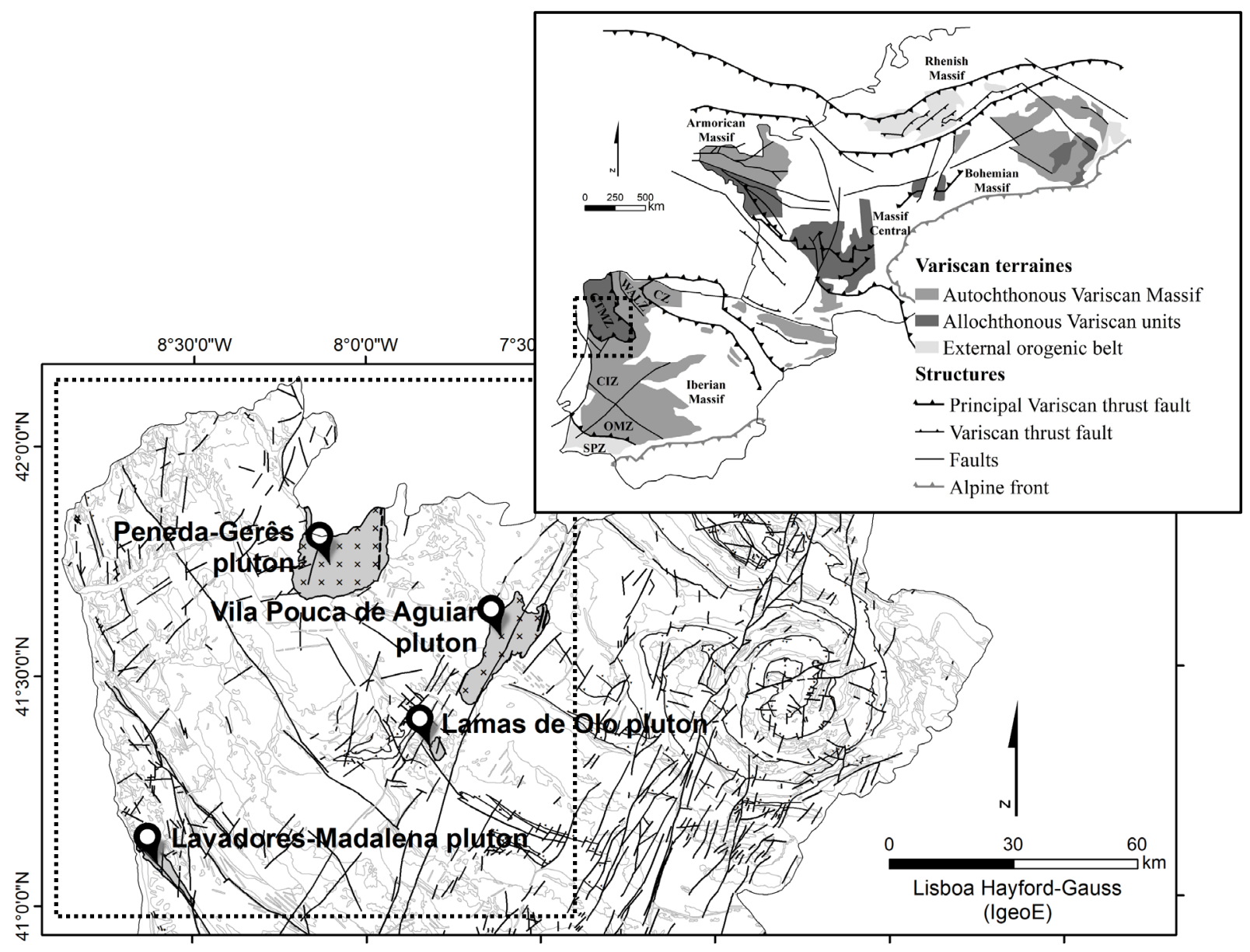

FIGURE 1. Iberian Variscan belt and location of the studied granitic bodies: Lamas de Olo Pluton, Vila Pouca de Aguiar Pluton, Peneda-Gerês Pluton and Lavadores-Madalena Pluton (modified from Ferreira et al., 1987). CZ: Cantabric Zone, WALZ: West Asturian Leonese Zone, GTMZ: Galiza Trásos-Montes Zone, CIZ: Central Iberian Zone, OMZ: Ossa Morena Zone, SPZ: South Portuguese Zone (based on: Farias et al., 1987; Julivert et al., 1974). 
structural levels, a brittle deformation occurred, leading to fracture-conjugate systems in a NNE-SSW and NNWSSE direction (Marques et al., 2002). $\mathrm{D}_{2}$ (ca. 337-316Ma; e.g. Dallmeyer et al., 1997; Díez Fernández et al., 2016; Martínez Catalán et al., 2014; Pereira et al., 2018) is well represented in allochthonous terranes in the GTMZ.

Most of the granite intrusions are coeval with $\mathrm{D}_{3}$ and the others are late- and post- $\mathrm{D}_{3}$ (e.g. Dias et al., 2010; Ferreira et al., 1987). The development of different tectonic structures, namely shear zones, during $\mathrm{D}_{3}$ and successive reactivation events controlled the granite emplacement and caused extensive hydrothermal activity throughout the entire crust, involving distinct fluid sources, some transporting significant amounts of ore mineral phases (Mateus and Noronha, 2010; Noronha et al., 2013).

\section{Plutons and associated mineralizations}

The LOP is located in the northern part of the CIZ near the limit with the GTMZ (Figs. 1;2). It is a small post-tectonic pluton with a rhombus shape, controlled by NNW-SSE offsets conjugated with the NNE-SSW fault system, which are parallel to the Verin-Régua-Penacova fault (VRPF). The LOP is composed of distinct outcropping granites (Fig. 2): i) Lamas de Olo (LO), the more representative, a mediumto coarse-grained porphyritic granite (biotite > muscovite); ii) Alto dos Cabeços (AC), a fine- to medium-grained porphyritic granite (biotite $>$ muscovite) and iii) Barragem (BA), a fine- to medium-grained slightly porphyritic leucocratic granite (biotite $=$ muscovite) (Fernandes et al., 2013; Pereira, 1989). ${ }^{207} \mathrm{~Pb} /{ }^{235} \mathrm{U}$ dating in monazite yield an age of $297.19 \pm 0.73 \mathrm{Ma}$ for the LO granite (Fernandes et al., 2013). Field observations show that the contact between the $\mathrm{LO}$ and $\mathrm{AC}$ granites is generally diffuse, and that the $\mathrm{BA}$ granite crosscuts the LO and AC granites. Previous studies of anisotropy of magnetic susceptibility showed that LOP has two types of behavior granites: magnetite- and ilmenitetype (Cruz et al., 2016). W-Mo (Sn) mineralizations occur, mostly in $\mathrm{N} 80^{\circ} \mathrm{E}$ sub-vertical quartz veins (Helal, 1992).

The LOP intrudes Lower Paleozoic formations (Armorican quartzite and schists of Upper Silurian to Middle Ordovician age), the Douro Group metasediments (Upper to Middle Cambrian) and two-mica syntectonic granites in the Vila Real Massif (Fig. 2). The Vila Real Massif is a syn- $\mathrm{D}_{3}$ two-mica granite composite massif with associated $\mathrm{Sn}$ mineralizations in pegmatites, and $\mathrm{W}-\mathrm{Sn}$ in hydrothermal quartz veins (Pereira, 1989). Monazite and zircon analysis yield a weighted average ${ }^{207} \mathrm{~Pb} /{ }^{235} \mathrm{U}$ age of ca. 311 $\pm 1 \mathrm{Ma}$ (Almeida et al., 1998).

The other granites referred to in this study belong to Vila Pouca de Aguiar, Peneda-Gerês and Lavadores-Madalena plutons (Fig. 1), classified as post-tectonic biotite plutons.
Vila Pouca de Aguiar and Peneda-Gerês plutons are located in the GTMZ and Lavadores-Madalena Pluton on the NW border of the CIZ.

The Vila Pouca de Aguiar Pluton is a composite pluton with two main biotite granites: Vila Pouca de Aguiar Granite (VPAG) and Pedras Salgadas Granite (PSG). The two granites have a similar mineralogical composition but different texture, with VPAG displaying a coarse grain porphyritic texture and PSG a more equigranular texture (Martins and Noronha, 2006; Sant'Ovaia et al., 2000). As regards their ages, PSG is younger than VPAG, with $297 \pm 14 \mathrm{Ma}$ and $298 \pm 9.1 \mathrm{Ma}$, respectively (Martins et al., 2009).

The Peneda-Gerês Pluton is also a composite pluton with three main granites: Gerês, Illa-Bouzagrado, and Carris. The Illa-Bouzagrado is a leucogranite (muscovite>biotite) and the other two are biotite granites (Cottard, 1979; Mendes and Dias, 2004). All the granites are contemporaneous and dated to ca. 290-296Ma (Dias et al., 1998). Some deposits associated with the granites of this pluton, have been described, namely: Mo (Bouzagrado in Spain) and W (MoSn-Bi) (Carris and Borrageiro in Portugal and Las Sombras in Spain) (Cottard, 1979; Cheilletz and Giuliani, 1982).

The Lavadores-Madalena Pluton, dated to $298 \pm 11 \mathrm{Ma}$ (Martins et al., 2011), is composed of Lavadores and Madalena granites. The Lavadores granite is a porphyritic, coarse-grained biotite granite (Martins et al., 2011) and the Madalena granite is a porphyritic medium- to coarsegrained biotite granite (Sant'Ovaia et al., 2014). W (Mo) mineralization associated with granites of this pluton has been described (Thadeu, 1965; Teixeira and Perdigão, 1962).

\section{MATERIAL AND METHODS}

Representative samples of different Variscan granites were examined. The sampled granites were from the Lamas de Olo Pluton, Vila Pouca de Aguiar Pluton, Peneda-Gerês Pluton and Lavadores-Madalena Pluton (Table 1; Fig. 1). Special attention was given to the LOP (Fig. 2), where 67 sites were sampled for this study.

To attain the primary objective of this work, different analytical methods were used: optical microscopy, magnetic susceptibility measurements, isothermal remanent magnetization acquisition curves, and thermomagnetic experiments. Previous studies (Cruz et al., 2016 for LOP. Martins and Noronha, 2006; Sant'Ovaia, 1993; Sant'Ovaia et al., 2000 for Vila Pouca de Aguiar Pluton. Cottard, 1979; Mendes and Dias, 2004 for Peneda-Gerês Pluton. Martins et al., 2011; Sant'Ovaia et al., 2014 for Lavadores- 


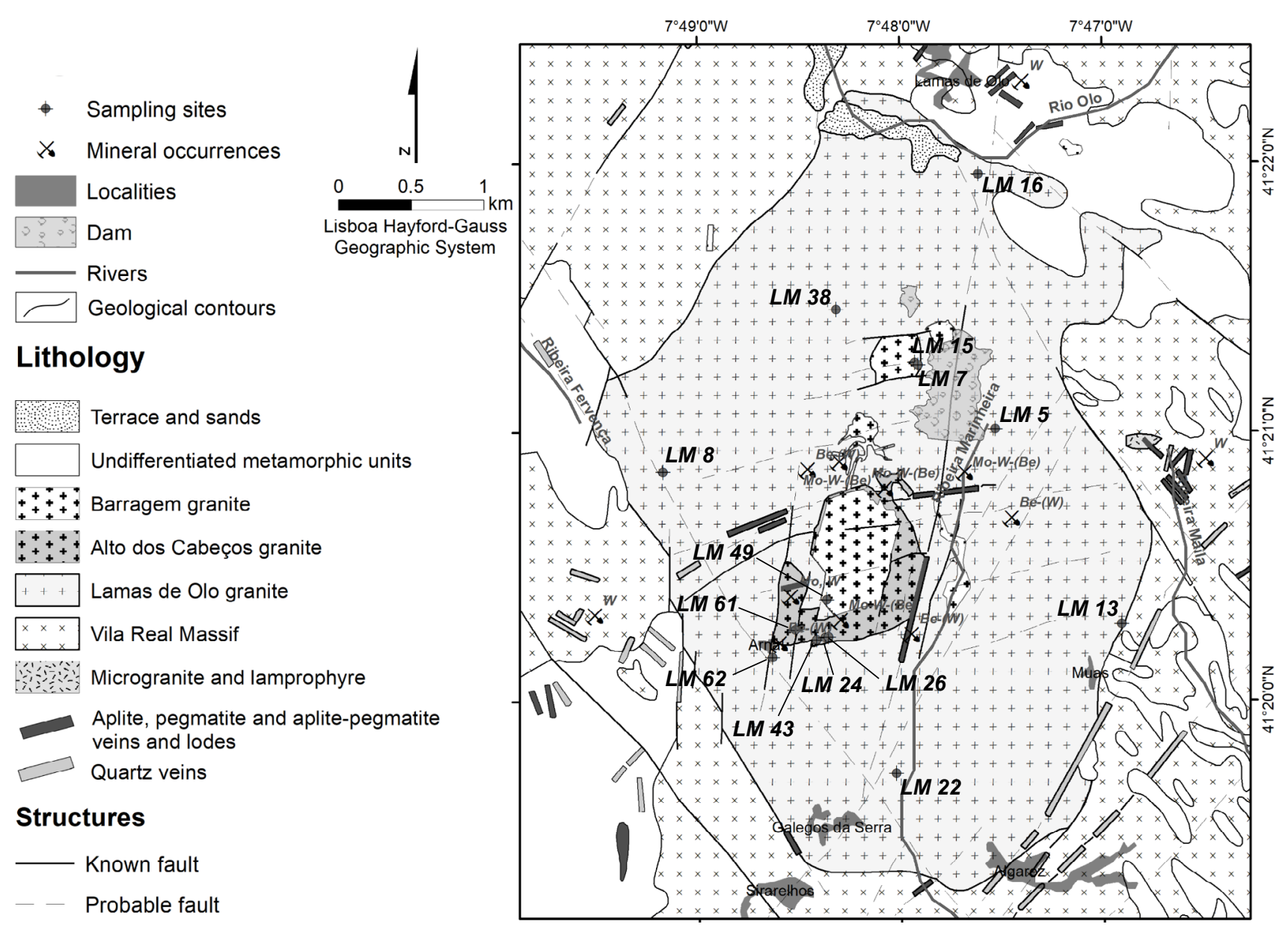

FIGURE 2. Simplified geological map from the Lamas de Olo Pluton (modified from Helal, 1992; Pereira et al., 1987; Pereira, 1989) and location of the samples (LM) used in the isothermal remanent magnetization acquisition curves, frequency-dependent susceptibility measurements and thermomagnetic experiments.

Madalena Pluton) were considered and their data compared with the new data (Table 1).

\section{Microscopy}

A Leica petrographic polarizing microscope with a digital camera was used for the reflected and transmitted light petrographic studies. The Raman spectra of different opaque minerals were obtained using a Raman LabRAM HORIBA Jobin Yvon Spex spectrometer interfaced with an Olympus microscope with 50x objective lens, diffraction gratings with 1,800 lines $\mathrm{mm}^{-1}$ and equipped with a $632.8 \mathrm{~nm}$ emission line of a HeNe laser at a power of $20 \mathrm{~mW}$. The incident beam perpendicular to the plane of the sample was focused through the microscope lens, which also collected the Raman scattered radiation in back-scattering geometry. A highly sensitive Charge-Coupled Device (CCD) camera was used to collect the Raman spectra. Extended scans were performed on a spectral range from 50 to $1,200 \mathrm{~cm}^{-1}$. The time of acquisition and the number of accumulations varied in order to obtain an optimized spectrum for each analyzed mineral. Both equipment belong to the Departamento de Geociências, Ambiente e Ordenamento do Território (DGAOT) of the Faculdade de Ciencias da Universidade do Porto (FCUP) and Instituto de Ciências da TerraPolo Porto (ICT-Porto).

Complementary studies to identify minor mineral amounts and characterize the magnetic mineralogy were carried out using a Scanning Electron Microscope (SEM) and Energy Dispersive Spectroscopy (EDS) X-ray microanalysis at the Centro de Materiais da Universidade do Porto (CEMUP). The SEM/EDS studies were performed using a high-resolution JEOL JSM 6301F SEM coupled with an Oxford INCA Energy 350 system. Samples were carbon-coated using a JEOL JEE-4X Vacuum Evaporator.

A total of 13 thin sections from the LOP were used for petrographic studies (Table 1). For complementary studies, some representative samples were selected: 4 for Raman (3 from LO and 1 from BA) and 5 for SEM/EDS ( 3 from LO and 1 from BA). These samples were selected taking into 
account the presence of magnetite, hematite, and ilmenite, which was previously identified under a microscope or by magnetic susceptibility studies. The results from other plutons were compiled from the literature (Table 1).

\section{Magnetic susceptibility and isothermal remanent magnetization}

The relationship between the magnetization induced in a material $M$ and the external field $H$ is defined as $M=K H$, where $K$ is the magnetic susceptibility. The $K$ reflects the whole-rock mineral composition, comprising the diamagnetic, paramagnetic and ferromagnetic minerals (Rochette, 1987). $K$ measurements were performed using a KLY-4S Kappabridge susceptometer Agico model (Czech Republic) from the DGAOT-FCUP and ICTPorto. Measurements were undertaken in a $300 \mathrm{~A} / \mathrm{m}$ field at room temperature. For each site, the ANISOFT 4.2 program package (Chadima and Jelinek, 2009) enabled us to calculate the mean susceptibility $\mathrm{K}_{m}$. The magnetite is an important ferromagnetic mineral (s.l.), easily detected because increases the $\mathrm{K}_{m}$ values to $>10^{-3} \mathrm{SI}$ (Bouchez, 1997, 2000; Tarling and Hrouda, 1993).

The magnetic susceptibility data were mostly compiled from the literature, and only a few samples from the PenedaGerês Pluton were measured in this study (Table 1).

For a detailed magnetic mineralogy study, the acquisition of Isothermal Remanent Magnetization (IRM) curves were performed. The IRM acquisition curves are important to estimate the characteristic coercivity of the ferromagnetic minerals (Butler, 1992). The IRM refers to the remanence acquired by a sample exposed to a direct magnetic field
$(H)$, at ambient temperature. These measurements were performed in the Laboratório de Paleomagnetismo at the Instituto Dom Luis, Lisboa. Beforehand, standard samples were demagnetized through an alternating field cleaning at ca. 100mT, with an LDA-3A (Agico) demagnetizer. Then, the magnetic field $(H)$ was imparted using an Impulse Magnetizer IM-10-30 (ASC Scientific) and the resulting remanence was measured using a spinner magnetometer JR-6A (Agico). Samples were magnetized in the same direction with increasing magnetic fields from $c a .3 .51 \mathrm{mT}$ up to $1.15 \mathrm{~T}$ in different steps ( $c a .40$ steps) and the induced magnetization acquired by the specimens was measured after each step of induction. Data were analyzed using a Cumulative Log-Gaussian (CLG) function (Robertson and France, 1994) with the software developed by Kruiver et al. (2001). For the IRM studies, 4 granite samples from the LOP were selected according to their magnetic behavior: 1 from the LO-magnetite-type granite, 1 from the LOilmenite-type granite, 1 from the BA granite and 1 from the AC granite (Table 1).

Additionally, measurements of frequency-dependent susceptibility were done with a Bartington MS2 System in the Laboratório de Paleomagnetismo at the Instituto Dom Luis, Lisboa. The low-field magnetic susceptibility was measured at two applied field frequencies $(0.46 \mathrm{kHz}$ and $46 \mathrm{kHz}$ ). The percentage of frequency-dependent susceptibility (KfD\%) (Dearing et al., 1996) was obtained in 10 samples from the LOP granites (Table 1).

\section{Thermomagnetic experiments}

The thermomagnetic experiments allow the identification of ferromagnetic minerals (s.l.) based on

TABLE 1. Methodologies applied to studied granites. LOP: Lamas de Olo Pluton; VPAP: Vila Pouca de Aguiar Pluton; PGP: Peneda-Gerês Pluton; LMP: Lavadores-Madalena Pluton; $\sqrt{ }$ : data obtained in this study; $\mathrm{x}$ : no data

\begin{tabular}{|c|c|c|c|c|c|c|}
\hline \multirow{2}{*}{ Pluton } & \multirow{2}{*}{ Granite } & \multicolumn{5}{|c|}{ Methodologies } \\
\hline & & $\begin{array}{l}\text { Optical microscopy } \\
\text { studies }\end{array}$ & $\begin{array}{l}\text { Magnetic susceptibility } \\
\text { studies }\end{array}$ & $\begin{array}{l}\text { Thermomagnetic } \\
\text { curves }\end{array}$ & $\begin{array}{l}\text { Isothermal remanent } \\
\text { magnetization }\end{array}$ & $\begin{array}{l}\text { Frequency-dependent } \\
\text { susceptibility }\end{array}$ \\
\hline \multirow{3}{*}{ LOP } & Lamas de Olo & $\checkmark$ (7 samples) & \multirow{3}{*}{ Cruz et al. (2016) } & $\checkmark$ (7 samples) & $\checkmark$ (2 samples) & $\checkmark$ (4 samples) \\
\hline & Alto dos Cabeços & $\checkmark$ (4 samples) & & $\checkmark$ (4 samples) & $\checkmark$ (1 sample) & $\checkmark$ (3 samples) \\
\hline & Barragem & $\checkmark$ (2 samples) & & $\checkmark$ (4 samples) & $\checkmark$ (1 sample) & $\checkmark$ (3 samples) \\
\hline \multirow[b]{2}{*}{ VPAP } & Pedras Salgadas & Sant'Ovaia (1993) & & $\checkmark$ (1 sample) & \multirow[b]{2}{*}{ Sant'Ovaia (1993) } & $x$ \\
\hline & Vila Pouca Aguiar & $\begin{array}{l}\text { Sant'Ovaia et al. (2000) } \\
\text { Martins and Noronha } \\
(2006)\end{array}$ & $\begin{array}{l}\text { Sant'Ovaia (1993) } \\
\text { Sant'Ovaia et al. (2000) }\end{array}$ & $x$ & & $x$ \\
\hline \multirow{3}{*}{ PGP } & Gerês & \multirow{3}{*}{$\begin{array}{l}\text { Mendes and Dias (2004) } \\
\text { Cottard (1979) }\end{array}$} & $\checkmark$ (7 samples) & $\checkmark$ (1 sample) & $x$ & $x$ \\
\hline & Illa & & $\checkmark$ (3 samples) & $x$ & $x$ & $x$ \\
\hline & Carris & & $\checkmark$ (3 samples) & $x$ & $x$ & $x$ \\
\hline \multirow[b]{2}{*}{ LMP } & Madalena & \multirow{2}{*}{$\begin{array}{l}\text { Martins et al. (2011) } \\
\text { Sant'Ovaia et al. (2014) }\end{array}$} & \multirow[b]{2}{*}{ Sant'Ovaia et al. (2014) } & $\checkmark$ (1 sample) & \multirow{2}{*}{$\begin{array}{l}\text { Martins et al. (2011) } \\
\text { Sant'Ovaia et al. } \\
\text { (2014) }\end{array}$} & $x$ \\
\hline & Lavadores & & & $\checkmark(1$ sample $)$ & & $x$ \\
\hline
\end{tabular}


their Curie/Néel temperature. The Curie temperature $\left(\mathrm{T}_{\mathrm{C}}\right)$ is the temperature above which a ferromagnetic material (s.s.) becomes paramagnetic, and the Néel temperature $\left(\mathrm{T}_{\mathrm{N}}\right)$ is analogous to the $\mathrm{T}_{\mathrm{C}}$ but for antiferromagnetic materials.

The Curie/Néel temperature of ferromagnetic minerals (s.l.) can be determined in low-field thermomagnetic experiments where the magnetic susceptibility of a sample is monitored while temperature is increased or decreased, and it is defined as the point of major decrease in magnetic susceptibility of the sample during the heating cycle (Butler, 1992). The temperature of this drop in magnetic susceptibility corresponds to the temperature at which a magnetic mineral loses its spontaneous magnetization. In contrast, if magnetic susceptibility, with values much lower than ferromagnetic values, decreases regularly with increasing temperature, the sample has the typical behavior of paramagnetic minerals (Dunlop and Özdemir, 1997).

The Curie/Néel temperature is typical for a particular mineral and is therefore commonly used to identify its composition. For example, the Curie/Néel temperature is $580^{\circ} \mathrm{C}$ for magnetite, $680^{\circ} \mathrm{C}$ for hematite, $320^{\circ} \mathrm{C}$ for pyrrhotite and $120^{\circ} \mathrm{C}$ for goethite. However, the rocks can have other iron minerals with titanium in their composition, corresponding to the titanomagnetite and titanohematite series. It should be noted that, in the titanomagnetite series, the Curie point decreases as the $\mathrm{Ti}$ content increases; therefore, the $\mathrm{T}_{\mathrm{C}}$ can range between $580^{\circ} \mathrm{C}\left(\mathrm{T}_{\mathrm{C}}\right.$ of pure magnetite) and $-150^{\circ} \mathrm{C}\left(\mathrm{T}_{\mathrm{C}}\right.$ of pure ulvospinel) (Dunlop and Özdemir, 1997).

The temperature dependence of low field magnetic susceptibility was monitored with a CS-2 furnace apparatus attached to the KLY-3 susceptometer (Agico) from the Laboratoire Géosciences Environnement Toulouse, Université de Toulouse III - Paul Sabatier, using samples obtained from 19 rock specimens (Table 1). Fifteen samples were selected in order to represent all LOP granites and their different magnetic behavior according to previous magnetic susceptibility studies. Regarding the other post-tectonic plutons, 4 samples were selected (Table 1).

The samples were exposed to increasing temperatures up to $700^{\circ} \mathrm{C}$ in heating/ cooling cycles. The measurements were made in an argon flux in order to minimize oxygen fugacity, which reduces the oxidation of the samples and the consequent formation of new minerals with the increase and/or decrease of temperature. However, a small amount of oxygen is always present in the sample holder, so although the probability is lower, some mineralogical changes may still occur.

\section{RESULTS AND DISCUSSION}

\section{Microscopy}

The LOP granites are mostly composed of quartz, plagioclase (oligoclase, albite, and oligoclase-andesine), $\mathrm{K}$-feldspars (orthoclase and microcline) and biotite (Table 2; Fig. 3A-C). As accessory minerals, muscovite I and/or II, zircon (Fig. 3A), sphene, allanite (Fig. 3D), fluorite (Fig. $3 \mathrm{E})$, hematite \pm magnetite \pm ilmenite, chlorite \pm rutile, apatite, goethite, epidote, and tourmaline are present. In the BA granite, the muscovite is more abundant than in the LO and $\mathrm{AC}$ granites but is mostly of secondary origin resulting from deuteric processes.

The plagioclases occur frequently zoned in all granites (Fig. 3C) and are albite-oligoclase in the BA granite, and oligoclase-andesine in the AC and LO granites. Occasionally, the plagioclases exhibit myrmekitic intergrowths with quartz, common mostly in the LO granite (Fig. 3F), and are altered by sericitization. The K-feldspar, perthitic orthoclase and microcline occur as heterogranular crystals. It is sometimes possible to observe some K-feldspar megacrystals with small plagioclase inclusions. The quartz has sometimes undulatory extinction, subgrain boundaries and fluid inclusion planes (Fig. 3G).

The biotite -brownish to greenish (Fig. 3E) in all granites- sometimes appears partially to completely chloritized. Occasionally, biotite is altered to muscovite, mainly in the leucocratic granite from BA, where biotite is observed in minor amounts (Fig. 3H). Frequently, biotite has pleochroic halos associated with zircon inclusions (Fig. $3 \mathrm{~A}$ ) and curved biotites are rare (Fig. $3 \mathrm{H}$ ).

For a detailed magnetic mineralogy characterization, complementary studies of opaque minerals were conducted to point out the presence of magnetite, hematite and/or ilmenite. The SEM/EDS analyses showed the presence of different Fe-Ox minerals (Fig. 4) and other minerals in small amounts, like monazite, xenotime (Fig. 4B) and columbo-tantalite. Figure $4 \mathrm{E}$ and $\mathrm{F}$ are examples of some EDS spectra performed in LOP thin sections, showing the presence of $\mathrm{Fe}-\mathrm{Ox}$ and $\mathrm{Fe}-\mathrm{Ox}$-Ti minerals. Figure 5 shows the micro-Raman spectrum of the principal magnetic minerals present in the LOP, namely magnetite (Fig. 5A), hematite (Fig. 5B) and ilmenite (Fig. 5C).

A summary of the petrographic descriptions of other Variscan granites made in previous studies is presented in Table 2. The Vila Pouca de Aguiar Pluton is located to the NE of the LOP, in the same NNE-SSW alignment, paralell to the Verin-Régua-Penacova Variscan fault. This pluton has two main granite facies with similar mineralogical composition. Both granites are composed 

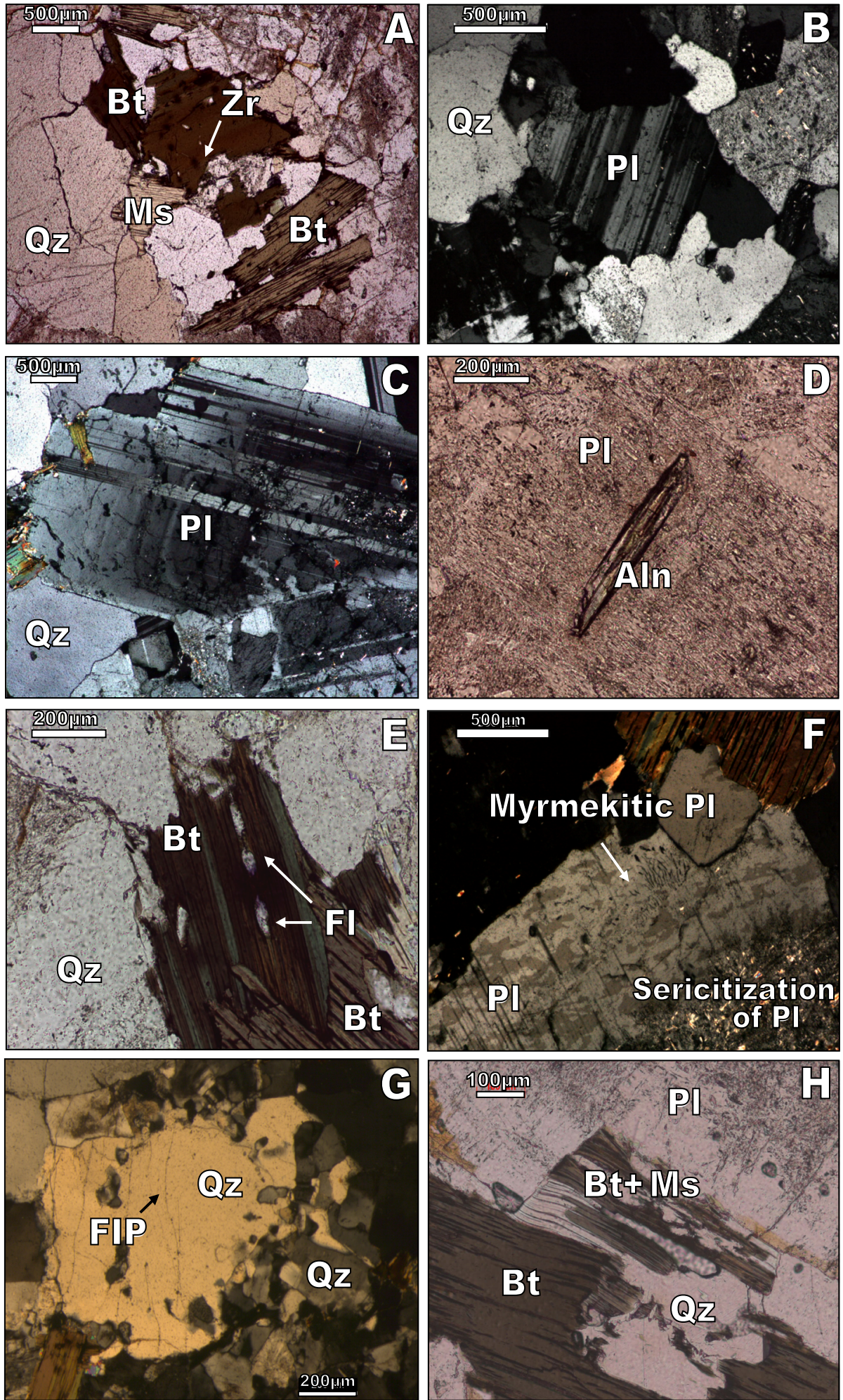

FIGURE 3. Photomicrographs of samples from the Lamas de Olo Pluton: A) Biotite and muscovite in plane-polarised light (Lamas de Olo granite); B, C) Plagioclase in crossed-polars (Barragem and Lamas de Olo granites, respectively); D) Alanite crystal on plagioclase in plane-polarised (Lamas de Olo granite); E) Biotite with brown and green colors cross-cutted by fluorite in plane-polarized (Lamas de Olo granite); F) Myrmekite texture and sericitization of plagioclase, in crossed-polars (Lamas de Olo granite); G) Microstructures in quartz, in crossed-polars (Lamas de Olo granite); $\mathrm{H}$ ) Curved micas in plane-polarized (Lamas de Olo granite). Bt: biotite, Zr: Zircon, Ms: muscovite, Qz: quartz, Pl: plagioclase, Aln: alanite, Fl: fluorite, FIP: fluid inclusion planes. 
TABLE 2. Mineralogy and texture description summary for the studied granites. LOP: Lamas de Olo Pluton; VPAP: Vila Pouca de Aguiar Pluton; PGP: Peneda-Gerês Pluton; LMP: Lavadores-Madalena Pluton. According to this study data and previous studies carried out by: Sant'Ovaia et al. (2000) and Martins and Noronha (2006) for VPAP; Mendes and Dias (2004) and Cottard (1979) for PGP; Martins et al. (2011) and Sant'Ovaia et al. (2014) for LMP

\begin{tabular}{|c|c|c|c|c|}
\hline Pluton & $\begin{array}{l}{ }^{207} \mathrm{~Pb} /{ }^{235} \mathrm{U} \\
\text { dating }\end{array}$ & Granite & Texture & Mineralogy \\
\hline \multirow{3}{*}{ LOP } & \multirow{3}{*}{$\begin{array}{l}\text { 297Ma } \\
\text { (Fernandes } \\
\text { et al., 2013) }\end{array}$} & Lamas de Olo & $\begin{array}{l}\text { Medium to coarse-grained } \\
\text { porphyritic biotite granite }\end{array}$ & \multirow{2}{*}{$\begin{array}{l}\text { Quartz, plagioclase, K-feldspar and biotite; zircon, sphene, allanite, } \\
\text { fluorite, hematite, magnetite, ilmenite, chlorite, rutile, apatite, goethite, } \\
\text { epidote, tourmaline, xenotime, monazite and rare muscovite I and/or II }\end{array}$} \\
\hline & & Alto dos Cabeços & $\begin{array}{l}\text { Fine to medium-grained } \\
\text { porphyritic biotite granite }\end{array}$ & \\
\hline & & Barragem & $\begin{array}{l}\text { Leucocratic fine to medium- } \\
\text { grained and slightly porphyritic } \\
\text { biotite granite }\end{array}$ & $\begin{array}{l}\text { Quartz, plagioclase, K-feldspar and biotite; muscovite I and/or II, } \\
\text { zircon, sphene, allanite, fluorite, hematite, ilmenite, chlorite, rutile, } \\
\text { apatite, goethite, epidote, tourmaline, xenotime and monazite }\end{array}$ \\
\hline \multirow{2}{*}{ VPAP } & \multirow{2}{*}{$\begin{array}{l}\text { 297-298Ma } \\
\text { (Martins et } \\
\text { al., 2009) }\end{array}$} & Pedras Salgadas & $\begin{array}{l}\text { Porphyritic fine to medium- } \\
\text { grained biotite monzogranite }\end{array}$ & $\begin{array}{l}\text { Quartz, perthitic K-feldspar, biotite and plagioclase; zircon, apatite, } \\
\text { allanite, xenotime, ilmenite, sphene and rare monazite }\end{array}$ \\
\hline & & Vila Pouca de Aguiar & $\begin{array}{l}\text { Porphyritic medium to coarse- } \\
\text { grained biotite monzogranite }\end{array}$ & $\begin{array}{l}\text { Quartz, perthitic K-feldspar, biotite and plagioclase; zircon, apatite, } \\
\text { allanite, xenotime, ilmenite and sphene }\end{array}$ \\
\hline \multirow{3}{*}{ PGP } & \multirow{3}{*}{$\begin{array}{l}\text { 290-296Ma } \\
\text { (Dias et al., } \\
\text { 1998) }\end{array}$} & Gerês & $\begin{array}{l}\text { Porphyritic medium to coarse- } \\
\text { grained biotite granite }\end{array}$ & $\begin{array}{l}\text { Perthitic K-feldspar, plagioclase, quartz and biotite; ilmenite, zircon, } \\
\text { apatite, allanite, sphene, monazite and scarce hornblende }\end{array}$ \\
\hline & & Illa & $\begin{array}{l}\text { Fine-grained two-mica } \\
\text { monzogranite }\end{array}$ & $\begin{array}{l}\text { Perthitic K-feldspar, plagioclase, quartz and biotite; muscovite I and/or } \\
\text { II, ilmenite, zircon, apatite and monazite }\end{array}$ \\
\hline & & Carris & $\begin{array}{l}\text { Medium to coarse-grained biotite } \\
\text { granite }\end{array}$ & $\begin{array}{l}\text { Perthitic K-feldspar, plagioclase, quartz and biotite; magnetite, ilmenite, } \\
\text { zircon, apatite and monazite }\end{array}$ \\
\hline \multirow[t]{2}{*}{ LMP } & \multirow{2}{*}{$\begin{array}{l}\sim 298 \mathrm{Ma} \\
\text { (Martins et } \\
\text { al., 2011) }\end{array}$} & Madalena & $\begin{array}{l}\text { Porphyritic medium to coarse- } \\
\text { grained biotite granite with } \\
\text { porphyritic texture }\end{array}$ & $\begin{array}{l}\text { Quartz, K-feldspar, plagioclase and biotite; magnetite, ilmenite, } \\
\text { hematite, zircon, apatite, muscovite and chlorite }\end{array}$ \\
\hline & & Lavadores & $\begin{array}{l}\text { Porphyritic coarse-grained biotite } \\
\text { granite }\end{array}$ & $\begin{array}{l}\text { Quartz, plagioclase, perthitic K-feldspar and biotite; magnetite, } \\
\text { ilmenite, hematite, zircon, sphene, apatite, allanite and amphibole }\end{array}$ \\
\hline
\end{tabular}

of quartz, perthitic K-feldspar (orthoclase and microcline) and plagioclase with normal zoning. The Vila Pouca de Aguiar granite contains also oligoclase-andesine and the Pedras Salgadas granite albite-oligoclase. The biotite, the only ferromagnesian phase, is more abundant in the Vila Pouca de Aguiar granite. Accessory minerals include zircon, apatite, allanite, xenotime, ilmenite, sphene and rare monazite (Martins and Noronha, 2006; Sant'Ovaia et al., 2000).

The three granites of the Peneda-Gerês Pluton, the northern pluton, are similar in their mineralogy. They contain perthitic K-feldspar, sometimes as megacrystals, plagioclase (albite-oligoclase, rarely andesine), quartz, biotite, ilmenite, zircon, apatite, and monazite. Some minerals are specific to some granites: allanite, sphene, and hornblende to the Gerês granite; muscovite to the Illa granite, resulting from later muscovitization; and magnetite to the Carris granite (Cottard, 1979; Mendes and Dias, 2004).

The Lavadores-Madalena Pluton is composed of two similar porphyritic, coarse-grained biotite granites. The Lavadores granite consists of quartz, plagioclase (andesine and oligoclase), perthitic K-feldspar (orthoclase and microcline), biotite, magnetite, ilmenite, hematite, zircon, sphene, apatite, allanite, and amphibole. The Madalena granite is composed of quartz, K-feldspar (orthoclase), plagioclase and biotite. Zircon, apatite, muscovite, chlorite, magnetite, ilmenite and hematite are present as accessory minerals (Martins et al., 2011; Sant'Ovaia et al., 2014).

\section{Magnetic mineralogy}

\section{Magnetic susceptibility and isothermal remanent magnetization data}

The magnetic susceptibility study in the post- $\mathrm{D}_{3}$ Variscan granites showed the presence of two types of magnetic behavior : ilmenite- and magnetite-type, with the predominance of the ilmenite-type $\left(\mathrm{K}_{m}<1,000 \mu \mathrm{SI}\right)$ (Table 3; Fig. 6). Previous studies in the LOP (Cruz et al., 2016) indicated that: i) the $\mathrm{K}_{m}$ values in the $\mathrm{LO}$ granite have a huge variability (ranging from low to high $\mathrm{K}_{m}$ ), ii) the $\mathrm{AC}$ granite has intermediate $\mathrm{K}_{m}$ values, and iii) the BA granite has the lower $\mathrm{K}_{m}$ values (Table 3 ). This data show that $\mathrm{LO}$ granite is the most heterogeneous granite of the pluton, suggesting that both ferromagnetic and paramagnetic behavior are present. On the other hand, the $\mathrm{AC}$ and $\mathrm{BA}$ granites have exclusively a paramagnetic behavior. So, the LOP is the most heterogeneous pluton, showing three $\mathrm{K}_{m}$ classes, below $50 \mu \mathrm{SI}$, between $50 \mu \mathrm{SI}$ and $2,000 \mu \mathrm{SI}$, and higher than 2,000 $\mu$ SI (Table 3; Fig. 6B). The Vila Pouca de Aguiar Pluton has minor $\mathrm{K}_{m}$ dispersion with values below $300 \mu \mathrm{SI}$, showing a typical ilmenite-type behavior (Sant'Ovaia et al., 2013a; Table 3; Fig. 6B). In the Peneda-Gerês Pluton, two granite facies are ilmenite-type and one is magnetite- and ilmenite-type. The granites from the Lavadores-Madalena Pluton have both minor $\mathrm{K}_{m}$ dispersion and the highest $\mathrm{K}_{m}$ mean values, always with $\mathrm{K}_{m}$ higher than $1,550 \mu \mathrm{SI}$ (Martins et al., 2011; Sant'Ovaia et al., 2014; Table 3; Fig. 6B).

The IRM data from the LOP are presented in Table 4 and Figure 7 . The LM 5 sample shows saturation at 

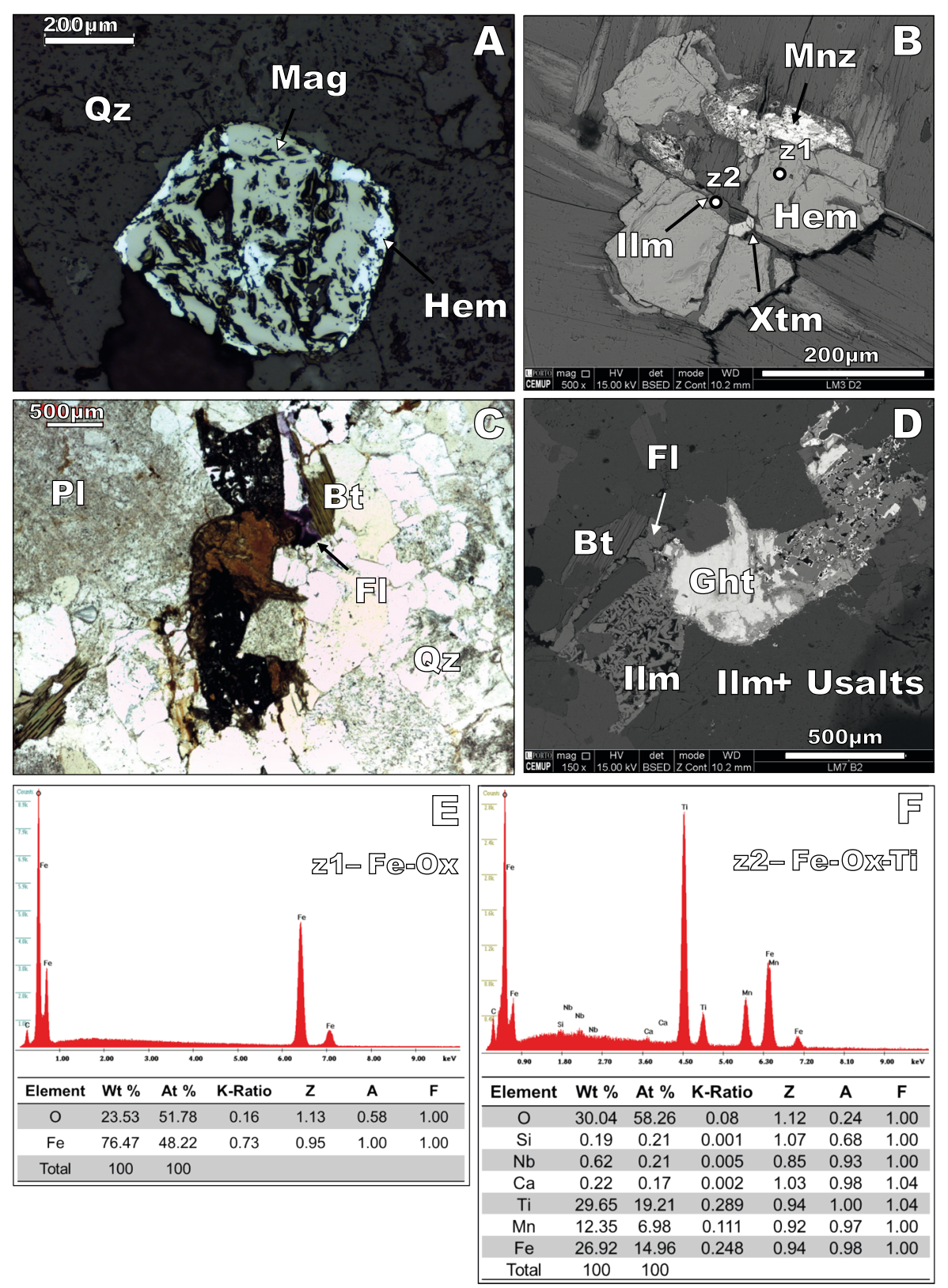

FIGURE 4. Photomicrographs (A-D) and EDS spectra of Lamas de Olo Pluton (E-F). A) Individual grain with magnetite and hematite, in reflected and plane-polarized light (Lamas de Olo granite); B) SEM image of Fe-Ox and other minerals in minor amounts with location of the EDS spectra z1 and z2 (Lamas de Olo granite); C) A mixture of Fe-Ox minerals in transmitted and plane-polarized light (Barragem granite); D) SEM image of the same textures shown in (C); E) EDS spectrum of a Fe-Ox mineral (z1) with semi-quantitative analyse; F) EDS spectrum of a Fe-Ox-Ti mineral (z2) with semi-quantitative analyse. Mag: magnetite, Hem: hematite, Qz: quartz, Bt: biotite, Mnz: monazite, IIm: ilmenite, Xtm: xenotime, Pl: plagioclase, Fl: fluorite, Ght: goethite, U salts: uranium salts; Fe-Ox: iron oxide; Fe-Ox-Ti: iron oxide with titanium.

fields $c a$. 338mT, suggesting the dominance of low coercive minerals, while LM 16 does not reach saturation at the maximum imparted field. The $\mathrm{S}_{0.3 \mathrm{~T}}$ for these samples is 0.999 and 0.839 , respectively, confirming the magnetic heterogeneity of the LO granite, with areas of predominance of low coercive minerals and areas where ferrimagnetic minerals are scarce. The curve for sample LM 26, from the AC granite, indicates higher amounts of ferrimagnetic minerals $\left(S_{0.3 \mathrm{~T}}=0.961\right)$, however does not show saturation at the applied field. The acquisition curve at $c a$. $950 \mathrm{mT}$ is apparently stable, however, a zoom shows a small increase in intensity with increasing fields, indicating a small amount of a high coercive mineral such as hematite. The LM 7 sample, from to the BA granite, shows some oscillations in the intensity with increasing fields due to a weak magnetic signal. However, the $S_{0.3 T}$ from this sample is 0.995 , suggesting the presence of low coercive minerals. 

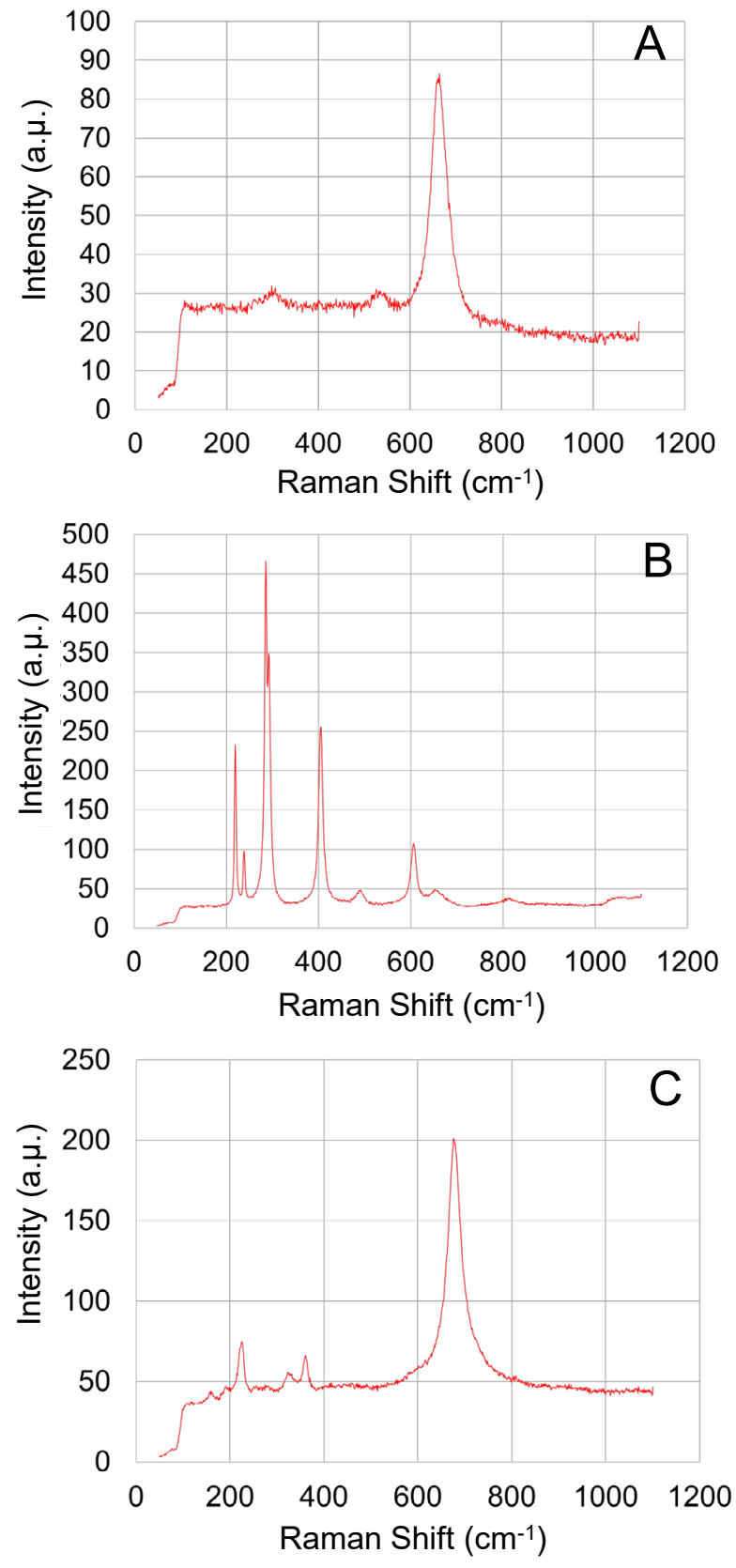

FIGURE 5. Micro-Raman spectra of Fe-Ox minerals from the Lamas de Olo Pluton: A) Magnetite; B) Hematite; C) Ilmenite.

After analising the data using the CLG function (Kruiver et al., 2001; Robertson and France, 1994), best fits of the raw IRM curves are obtained by considering two or three components (Table 4; Fig. 7). All specimens have, at least two components: component 1 with low coercive phase and $\mathrm{B}_{1 / 2}$ (the field at which half of the SIRM is reached) $c a$. $17 \mathrm{mT}$ and component 2 , showing an intermediated coercive phase and $\mathrm{B}_{1 / 2} c a$. $59 \mathrm{mT}$. Two samples show a third component, with higher coercivity with $\mathrm{B}_{1 / 2} c a$. $466 \mathrm{mT}$.
The Dispersion Parameter (DP) ranges between 0.25 and 0.42 for all components, with mean values of $0.36,0.31$ and 0.34 for component 1, 2 and 3, respectively. According to Dunlop and Özdemir (1997), the coercivity increases with the replacement of $\mathrm{Fe}^{3+}$ by $\mathrm{Ti}$ in titanomagnetite. Taking this into account, the components 1,2 and 3 have been interpreted as magnetite, Ti-poor magnetite and hematite, respectively (Abrajevitch and Kodama, 2011; Font et al., 2014; Kruvier et al., 2001; Maxbauer et al., 2016; Robertson and France, 1994). Ti-poor magnetite (component 2) is dominant in all samples (contributes to more than $50 \%$ of the total remanence), with exception of LM 7 with $13 \%$ of Ti-poor magnetite and $87 \%$ of magnetite (component 1; Table 4).

According to some authors (e.g. Font et al., 2009; Font et al., 2014; Kruiver et al., 2001), the differences in $\mathrm{B}_{1 / 2}$ and DP values can be interpreted as: varying degrees of oxidation of magnetite for component 1; different Ticontent in the Ti-poor magnetite for component 2; and different magnetic grain sizes for component 3 .

IRM studies carried out by Sant'Ovaia (1993) in the Vila Pouca de Aguiar Pluton showed that the Vila Pouca de Aguiar and Pedras Salgadas granites have similar magnetic behavior. The $\mathrm{S}_{0.3 \mathrm{~T}}$ ranges between 0.624 and 0.968 , with minor values obtained in the Pedras Salgadas granite. Both granites show an absence of saturation, however, the Pedras Salgadas granite presents an acquisition curve with a high slope, showing the depletion of ilmenite (Table 4; Fig. 8). Previous studies in the Lavadores-Madalena Pluton showed saturation fields under 300mT and $\mathrm{S}_{0.3 \mathrm{~T}}$ values higher than 0.955 (Table 4; Fig. 8), pointing out high ferromagnetic mineral content (Martins et al., 2011; Sant'Ovaia et al., 2014).

Frequency-dependent susceptibility (KfD\%) studies were made in LOP samples. In the BA granite, KfD\% was higher than 10\% (LM $7 \sim 35 \%$; LM $58 \sim 29 \%$ and LM $62 \sim 30 \%$ ), which have been interpreted by some authors (e.g. Dearing et al., 1996) as due to the presence of superparamagnetic fine grains, a weak magnetic signal or a high alteration degree. On the other hand, the values acquired for the LO samples $(\mathrm{KfD} \%<2 \%)$ indicated absence of superparamagnetic grains, and for the AC samples (4\% $<\mathrm{KfD} \%<7 \%$ ) an admixture of superparamagnetic and coarser non-superparamagnetic grains (Dearing et al., 1996). The presence of superparamagnetic minerals in samples from the BA granite could explain the lower values of the magnetic susceptibility (mean $\mathrm{K}_{m}$ ca. $27 \mu \mathrm{SI}$ ) and the presence of low coercive minerals.

\section{Thermomagnetic experiments}

Figures 9 and 10 show different magnetic susceptibilitytemperature curves ( $K t v s$ T charts) obtained from samples 
TABLE 3. Magnetic mineralogy of studied granites according to this study data and previous studies carried out by: Cruz et al. (2016) for LOP; Sant'Ovaia (1993) and Sant'Ovaia et al. (2013) for VPAP; Sant'Ovaia et al. (2013) for PGP; Martins et al. (2011) and Sant'Ovaia et al. (2014) for LMP. The maghemite appears between brackets because it is a neoformation mineral due to oxidation of magnetite during thermomagnetic experiments. LOP: Lamas de Olo Pluton; VPAP: Vila Pouca de Aguiar Pluton; PGP: Peneda-Gerês Pluton; LMP: Lavadores-Madalena Pluton, and associated mineralizations; N: number of sampling sites; $n$ : number of samples; $n$.a.: not attributed

\begin{tabular}{|c|c|c|c|c|c|c|c|c|c|}
\hline \multirow[b]{2}{*}{ Pluton } & \multirow[b]{2}{*}{ Granite } & \multirow[b]{2}{*}{ Magnetic behavior } & \multicolumn{4}{|c|}{$K_{m}(\mu \mathrm{SI})$} & \multicolumn{2}{|c|}{ Magnetic mineralogy } & \multirow[t]{2}{*}{$\begin{array}{c}\text { Associated } \\
\text { mineralizations }\end{array}$} \\
\hline & & & mean & range & $\mathrm{N}$ & $\mathrm{n}$ & $\begin{array}{l}\text { Magnetic susceptibility studies } \\
\text { and thermomagnetic } \\
\text { experiments }\end{array}$ & $\begin{array}{l}\text { Cumulative log- } \\
\text { Gaussian analysis }\end{array}$ & \\
\hline \multirow{3}{*}{ LOP } & Lamas de Olo & $\begin{array}{l}\text { Magnetite- and } \\
\text { ilmenite-type }\end{array}$ & 2,078 & $67-44,382$ & 39 & 293 & $\begin{array}{l}\text { Ti-poor magnetite }+ \text { hematite }+ \\
\text { pure magnetite }+ \text { ilmenite } \\
(+ \text { maghemite })\end{array}$ & $\begin{array}{l}\text { Ti-poor magnetite } \\
>\text { magnetite > hematite }\end{array}$ & \multirow{3}{*}{ W-Mo } \\
\hline & $\begin{array}{l}\text { Alto dos } \\
\text { Cabeços }\end{array}$ & IImenite-type & 334 & $125-804$ & 4 & 29 & $\begin{array}{l}\text { Ti-poor magnetite }+ \text { ilmenite }+ \\
\text { hematite }+ \text { magnetite } \\
(+ \text { maghemite })\end{array}$ & $\begin{array}{l}\text { Ti-poor magnetite }> \\
\text { magnetite }>\text { hematite }\end{array}$ & \\
\hline & Barragem & IImenite-type & 27 & $21-34$ & 5 & 28 & $\begin{array}{l}\text { Hematite + ilmenite + Ti-poor } \\
\text { magnetite + magnetite }\end{array}$ & $\begin{array}{l}\text { Magnetite > Ti-poor } \\
\text { magnetite }\end{array}$ & \\
\hline \multirow{2}{*}{ VPAP } & $\begin{array}{l}\text { Pedras } \\
\text { Salgadas }\end{array}$ & IImenite-type & 68 & $44-121$ & 35 & 280 & $\begin{array}{l}\text { Hematite + ilmenite + Ti-poor } \\
\text { magnetite }\end{array}$ & (5) & \multirow{2}{*}{$\begin{array}{l}\text { Without } \\
\text { mineralizations }\end{array}$} \\
\hline & $\begin{array}{l}\text { Vila Pouca de } \\
\text { Aguiar }\end{array}$ & IImenite-type & 135 & $60-218$ & 81 & 648 & $\begin{array}{l}\text { Hematite + ilmenite + Ti-poor } \\
\text { magnetite }\end{array}$ & n.a & \\
\hline \multirow{3}{*}{ PGP } & Gerês & $\begin{array}{l}\text { Magnetite- and } \\
\text { ilmenite-type }\end{array}$ & 463 & $46-1,000$ & 7 & 7 & $\begin{array}{l}\text { Hematite + Ti-poor magnetite + } \\
\text { ilmenite }\end{array}$ & n.a & \multirow{3}{*}{$\begin{array}{l}\text { W-Mo } \\
\text { Mo } \\
\text { W-Sn-Mo-Bi }\end{array}$} \\
\hline & Illa & IImenite-type & 81 & $55-109$ & 3 & 3 & $\begin{array}{l}\text { Hematite + ilmenite + Ti-poor } \\
\text { magnetite }\end{array}$ & n.a & \\
\hline & Carris & IImenite-type & 33 & $29-36$ & 3 & 3 & $\begin{array}{l}\text { Hematite + Ti-poor magnetite + } \\
\text { ilmenite }\end{array}$ & n.a & \\
\hline \multirow{2}{*}{ LMP } & Madalena & Magnetite-type & 7,037 & $1,550-9,920$ & 7 & 80 & $\begin{array}{l}\text { Ti-poor magnetite }+ \text { ilmenite }+ \\
\text { hematite }(+ \text { maghemite })\end{array}$ & n.a & \multirow{2}{*}{ W-Mo } \\
\hline & Lavadores & Magnetite-type & 15,971 & $\begin{array}{r}10,589- \\
19,303\end{array}$ & 6 & 40 & $\begin{array}{l}\text { Magnetite + ilmenite + hematite } \\
(+ \text { maghemite })\end{array}$ & n.a & \\
\hline
\end{tabular}

of the Variscan granites. It should be noted that in the $K_{t} v s$ $\mathrm{T}$ charts the susceptibility data, on the y-axes, is referred to as total or bulk susceptibility $\left(K_{t}\right)$, and it is not corrected by volume or mass. These values are, therefore, quite different from the $K_{m}$ values measured in the magnetic susceptibility experiments, where the $K_{m}$ values are corrected for the specimen volume or mass.

The $K_{t} v s$ T curves from selected LO granite samples show a significant fall of $K_{t}$ at $c a .580^{\circ} \mathrm{C}$, indicating magnetite $\mathrm{T}_{\mathrm{C}}$ (Fig. 9A). Other curves have a $K_{t}$ drop just before $580^{\circ} \mathrm{C}$ corresponding to a Ti-poor magnetite (Fig. $9 \mathrm{~B}, \mathrm{C}, \mathrm{D})$. Some samples have a slighter drop than the others because they have a smaller Ti-poor magnetite content (Fig. 9D). The $K_{t} v s$ T curves from BA samples show the presence of hematite (Fig. 9E, F, G), and some traces of Ti-poor magnetite. The $K_{t}$ values in the AC granite are, in general, lower than in the $\mathrm{LO}$ granite, but some $\mathrm{K}_{t} v s \mathrm{~T}$ curves show a slight drop just before $580^{\circ} \mathrm{C}$, pointing to an ilmenite-type granite, but probably with some traces of Ti-poor magnetite (Fig. 9H, I). This could be related to the circulation of postmagmatic fluids capable of changing the characteristics of the primary magnetic minerals with the formation of new, less magnetic minerals, like hematite, maghemite or goethite (Lagoeiro, 1998; Nédélec et al., 2015). All the LOP curves show the presence of hematite and, in some
A

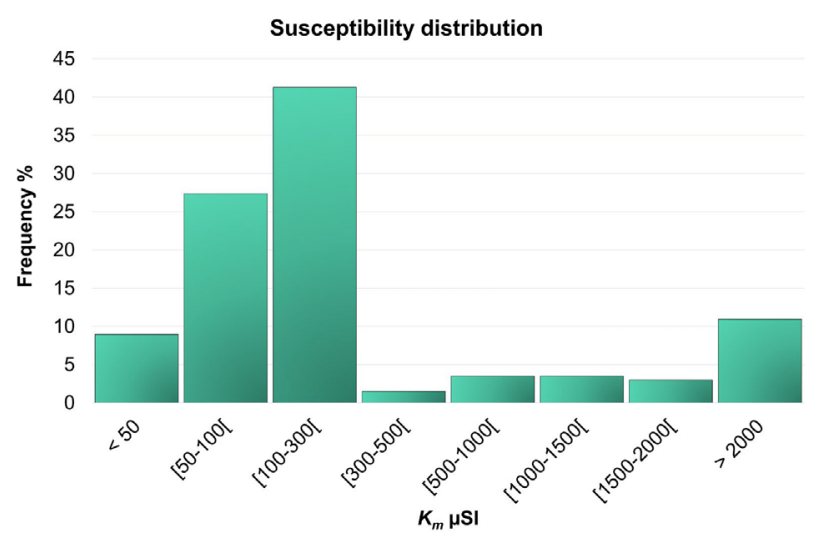

B

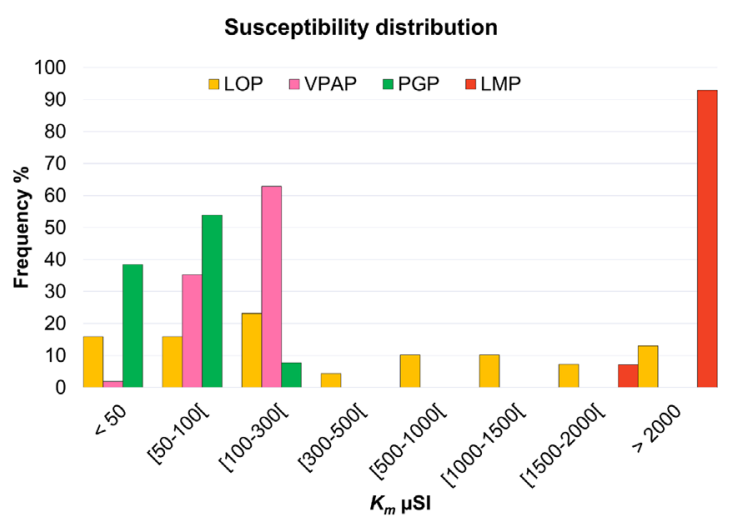

FIGURE 6. Relative frequency magnetic susceptibility histograms: A) for all the studied granites; B) for the plutons; LOP: Lamas de Olo Pluton; VPAP: Vila Pouca de Aguiar Pluton, PGP: Peneda-Gerês Pluton, LMP: Lavadores-Madalena Pluton. 


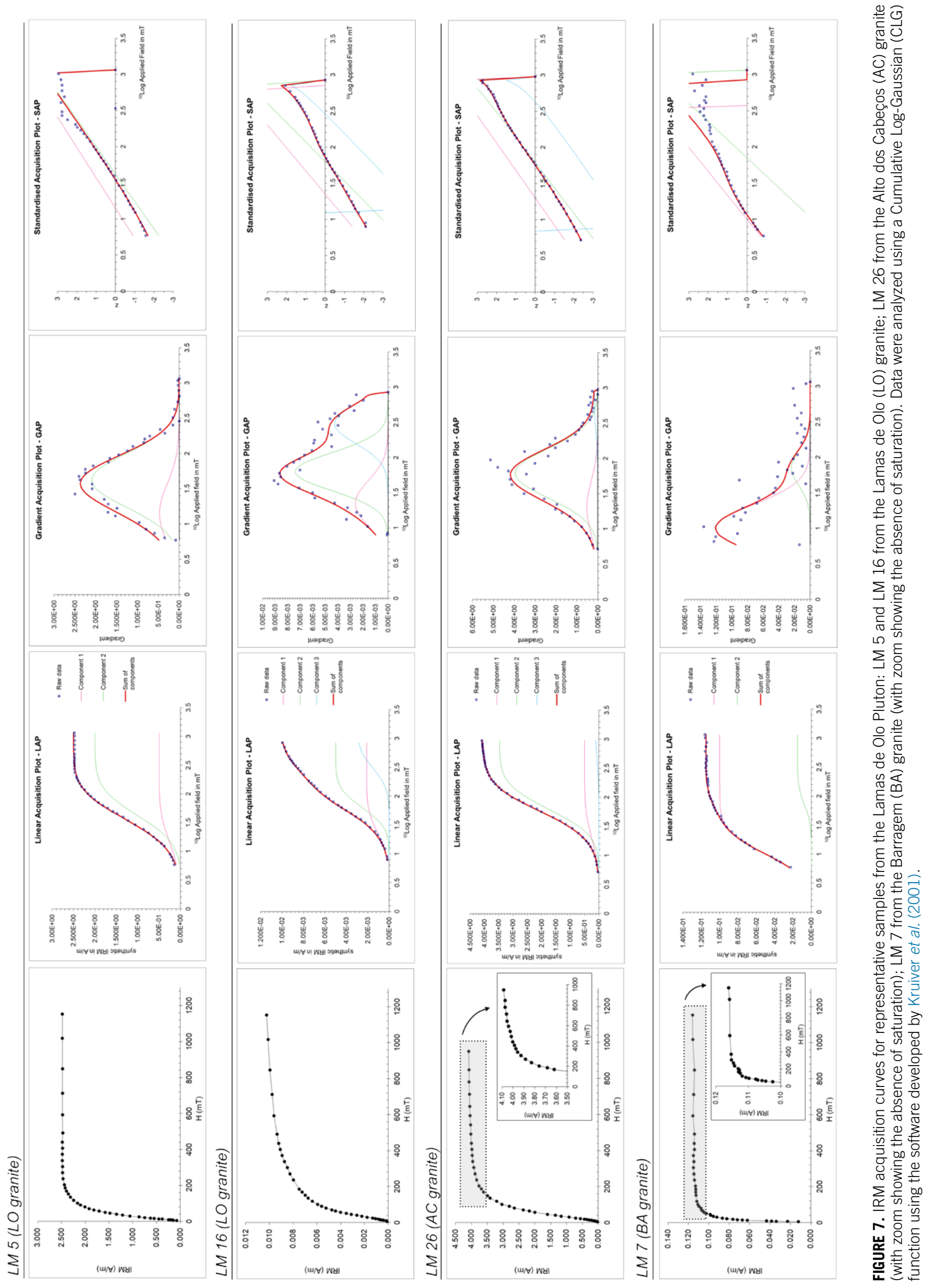


Sample 1.40 - Pedras Salgadas granite (VPAP)

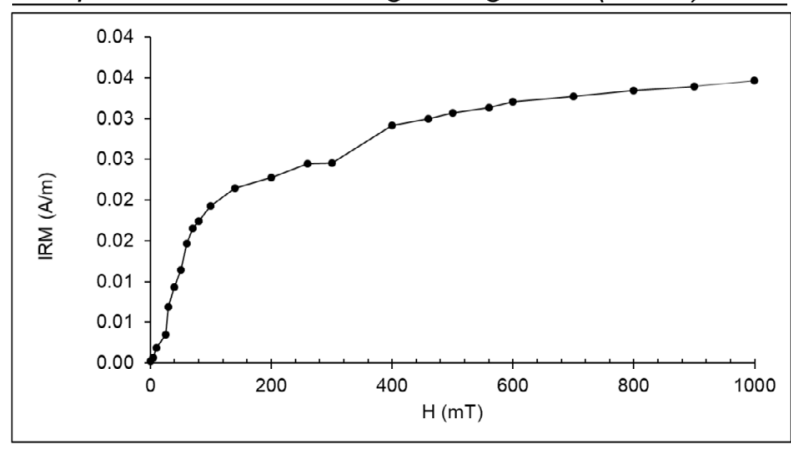

\section{Sample Canelas - Madalena granite (LMP)}

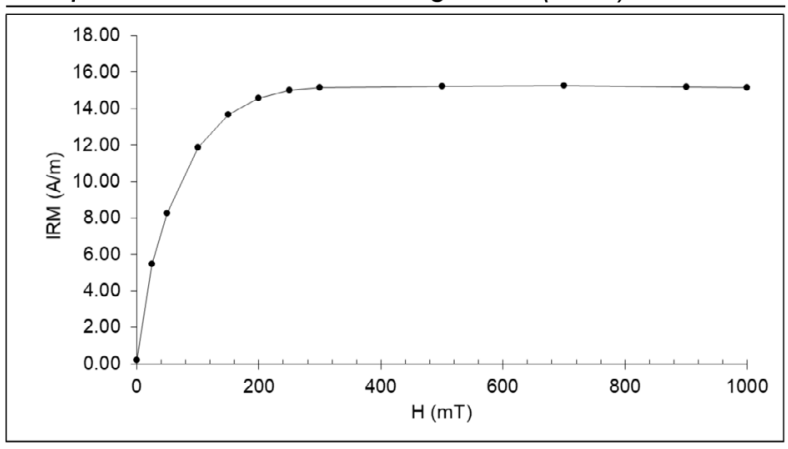

\section{Sample 8.1T - Vila Pouca de Aguiar granite (VPAP)}

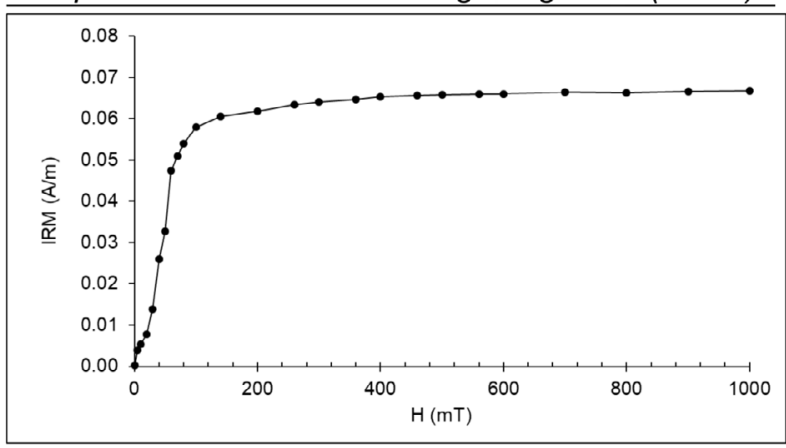

\section{Sample Cabedelo - Lavadores granite (LMP)}

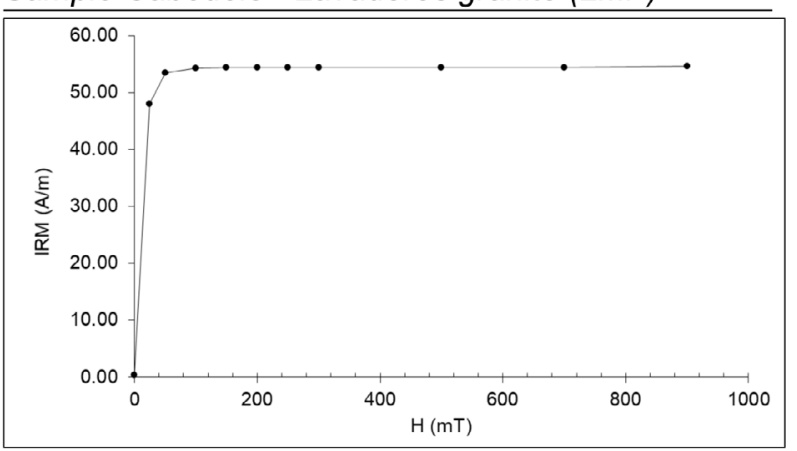

FIGURE 8. Examples of IRM acquisition curves from the Vila Pouca de Aguiar Pluton (VPAP) and the Lavadores-Madalena Pluton (LMP) from earlier studies (Martins et al., 2011; Sant'Ovaia et al., 1993; Sant'Ovaia et al., 2014).

TABLE 4. Isothermal remanent magnetization data from the studied plutons. Vila Pouca de Aguiar Pluton (VPAP) and Lavadores-Madalena Pluton

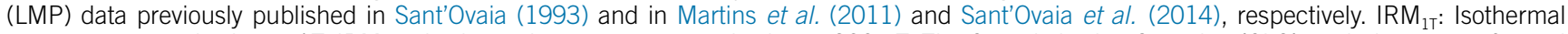
remanent magnetization at $1 \mathrm{~T} ; \mathrm{IRM}_{0.3 \mathrm{~T}}$ : isothermal remanent magnetization at $300 \mathrm{mT}$. The Cumulative log-Gaussian (CLG) analysis were performed only in the LOP samples; CLG treatment allows defining for each magnetic component, \%: percent contribution; SIRM: values of saturation of isothermal remanent magnetization; $B_{1 / 2}$ : the field at which half of the SIRM is reached; DP: dispersion parameter; $S_{0.3 T}=I^{I R M} M_{0.33} / I R M_{1 T}(R o b e r t s o n$ and France, 1994). The CLG treatment was made using the software developed by Kruiver et al. (2001). n.a.: not attributed

\begin{tabular}{|c|c|c|c|c|c|c|c|c|c|c|c|c|c|c|c|c|c|}
\hline \multirow{3}{*}{ Pluton } & \multirow{3}{*}{ Granite } & \multirow{3}{*}{ Sample } & \multirow{3}{*}{$\begin{array}{l}\mathrm{IRM}_{1 \mathrm{~T}} \\
(\mathrm{~A} / \mathrm{m})\end{array}$} & \multirow{3}{*}{$\begin{array}{r}\mathrm{IRM}_{0.3 \mathrm{~T}} \\
(\mathrm{~A} / \mathrm{m})\end{array}$} & \multirow{3}{*}{$\mathrm{S}_{0.3 \mathrm{~T}}$} & \multicolumn{12}{|c|}{ CLG analysis } \\
\hline & & & & & & \multicolumn{4}{|c|}{ Component $1(20-40 \mathrm{mT})$} & \multicolumn{4}{|c|}{ Component $2(50-80 \mathrm{mT})$} & \multicolumn{4}{|c|}{ Component $3(100-250 \mathrm{mT})$} \\
\hline & & & & & & $\%$ & $\begin{array}{l}\text { SIRM } \\
(A / m)\end{array}$ & $\begin{array}{l}\mathrm{B}_{1 / 2} \\
(\mathrm{mT})\end{array}$ & DP & $\%$ & $\begin{array}{l}\text { SIRM } \\
(\mathrm{A} / \mathrm{m})\end{array}$ & $\begin{array}{r}\mathrm{B}_{1 / 2} \\
(\mathrm{mT})\end{array}$ & $\mathrm{DP}$ & $\%$ & $\begin{array}{l}\text { SIRM } \\
(\mathrm{A} / \mathrm{m})\end{array}$ & $\begin{array}{r}\mathrm{B}_{1 / 2} \\
(\mathrm{mT})\end{array}$ & DP \\
\hline \multirow{4}{*}{ LOP } & \multirow{2}{*}{ Lamas de Olo } & LM 5 & 2.480 & 2.477 & 0.999 & 20 & 0.50 & 14.13 & 0.42 & 80 & 2.00 & 41.69 & 0.38 & & & & \\
\hline & & LM 16 & 0.010 & 0.008 & 0.839 & 21 & 0.00 & 22.39 & 0.32 & 50 & 0.01 & 63.10 & 0.27 & 30 & 0.00 & 302.00 & 0.28 \\
\hline & Alto dos Cabeços & LM 26 & 4.086 & 3.925 & 0.961 & 12 & 0.50 & 19.95 & 0.38 & 84 & 3.47 & 61.66 & 0.35 & 4 & 0.17 & 630.96 & 0.4 \\
\hline & Barragem & LM 7 & 0.116 & 0.115 & 0.995 & 87 & 0.10 & 10.00 & 0.33 & 13 & 0.02 & 70.79 & 0.25 & & & & \\
\hline \multirow{6}{*}{ VPAP } & \multirow{2}{*}{ Pedras Salgadas } & 1.40 & 0.035 & 0.025 & 0.706 & & & & & & \multirow{12}{*}{ n.a } & & & & & & \\
\hline & & $4.2 \mathrm{~T}$ & 0.015 & 0.009 & 0.624 & & & & & & & & & & & & \\
\hline & \multirow{4}{*}{$\begin{array}{l}\text { Vila Pouca de } \\
\text { Aguiar }\end{array}$} & $13.4 \mathrm{~T}$ & 0.024 & 0.022 & 0.883 & & & & & & & & & & & & \\
\hline & & 12.20 & 0.021 & 0.019 & 0.881 & & & & & & & & & & & & \\
\hline & & $8.1 \mathrm{~T}$ & 0.067 & 0.064 & 0.959 & & & & & & & & & & & & \\
\hline & & $11.4 \mathrm{~T}$ & 0.061 & 0.059 & 0.968 & & & & & & & & & & & & \\
\hline \multirow{6}{*}{ LMP } & \multirow{5}{*}{ Madalena } & Cavadão & 13.313 & 13.273 & 0.997 & & & & & & & & & & & & \\
\hline & & Canelas & 15.160 & 15.158 & 1.000 & & & & & & & & & & & & \\
\hline & & Carvalhos & 53.520 & 52.786 & 0.986 & & & & & & & & & & & & \\
\hline & & Saúde & 16.618 & 15.870 & 0.955 & & & & & & & & & & & & \\
\hline & & Pedroso & 32.060 & 33.566 & 1.047 & & & & & & & & & & & & \\
\hline & Lavadores & Cabedelo & 54.621 & 54.435 & 0.997 & & & & & & & & & & & & \\
\hline
\end{tabular}



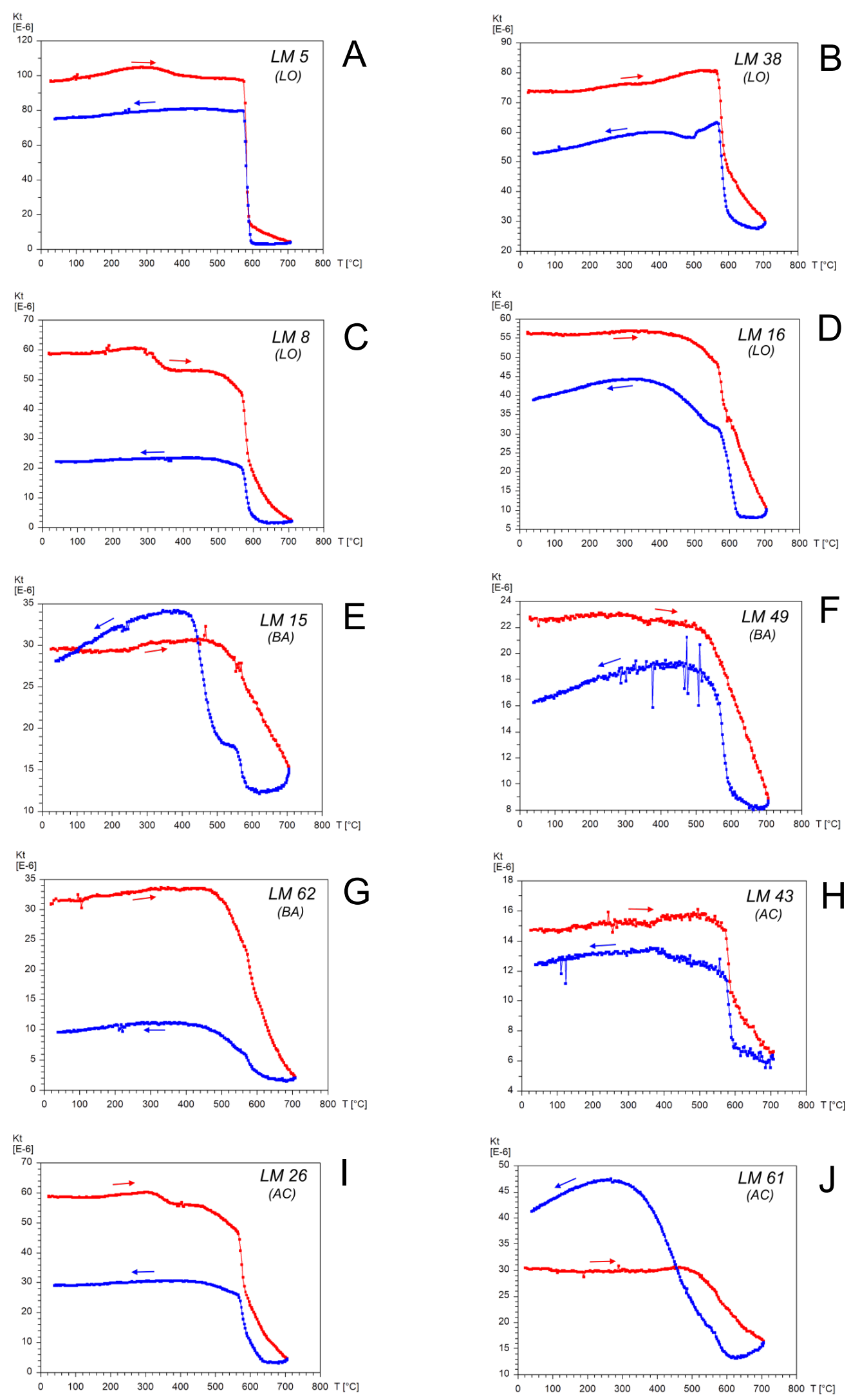

FIGURE 9. Normalized $K_{t}$ vs T during heating (red arrow toward right) and cooling (blue arrow toward left) from representative samples of LOP granites: A-D) from the Lamas de Olo (LO) granite; E-G) from the Barragem (BA) granite; H-J) from the Alto dos Cabeços (AC) granite. Note that the $\mathrm{y}$-axes are not on the same scale in all charts, so it is necessary to consider the $K_{t}$ values themselves. 

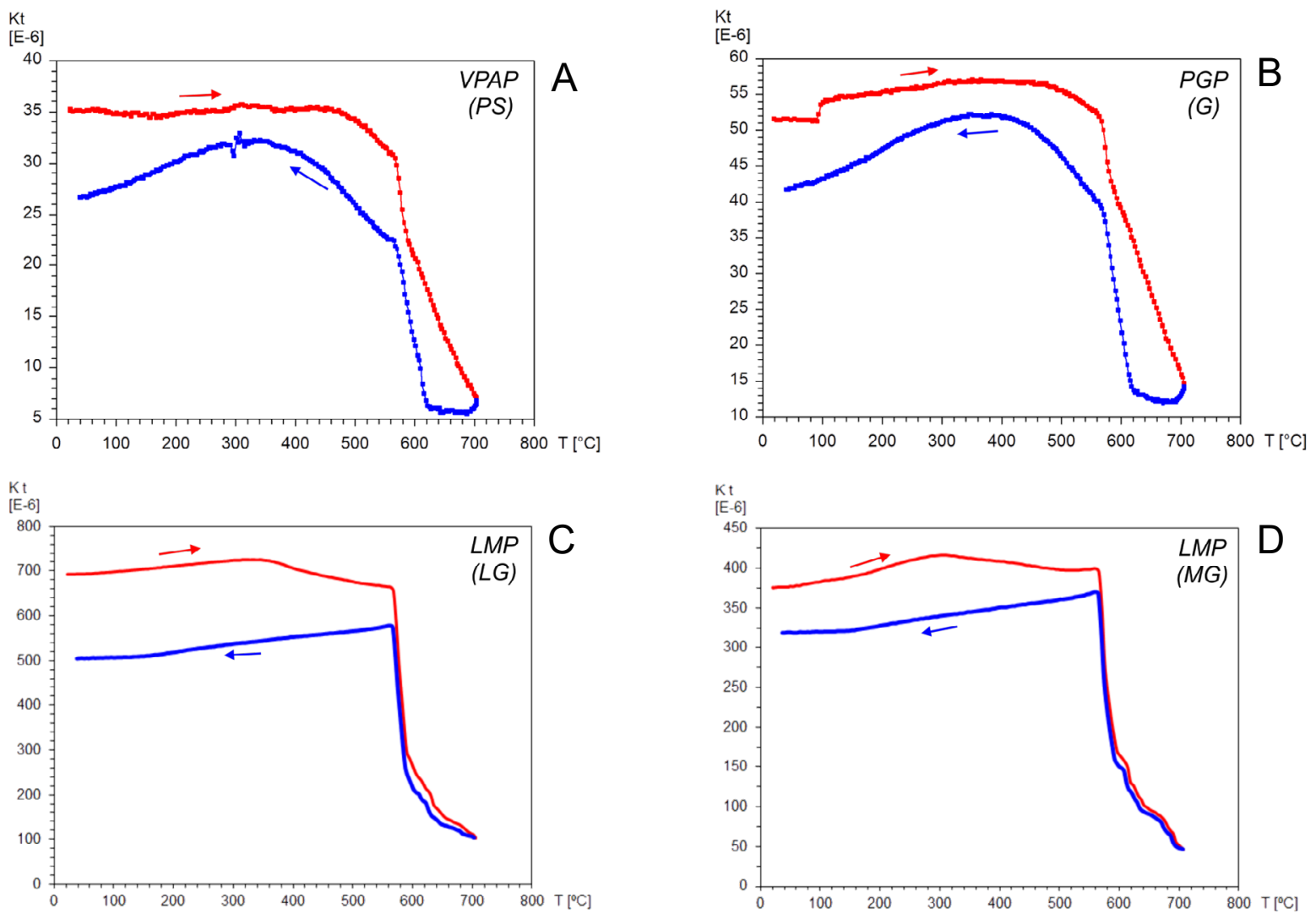

FIGURE 10. Normalized $K_{t} v S$ T during heating (red arrow toward right) and cooling (blue arrow toward left) from Variscan granites other than the LOP granites: A) Pedras Salgadas granite from the Vila Pouca de Aguiar Pluton (VPAP-PS); B) Gerês granite from the Peneda-Gerês Pluton (PGP-G); C) Lavadores granite from the Lavadores-Madalena Pluton (LMP-LG) and D) Madalena granite from the Lavadores-Madelena Pluton (LMP-MG).

cases (Fig. 9E, J), during the cooling cycle, below $580^{\circ} \mathrm{C}$, $\mathrm{K}_{\mathrm{t}}$ progressively increases, surpassing the values attained in the heating curve, suggesting the formation of a magnetic mineral, probably Ti-poor magnetite.

In some $K_{t} v s$ T curves from the $\mathrm{LO}$ and $\mathrm{AC}$ granites, an inflection around $300^{\circ} \mathrm{C}$ was observed on the heating curves (Fig. 9A, C, I). This inflection may correspond to pyrrhotite or to maghemite. The pyrrhotite is a ferromagnetic mineral, with $\mathrm{T}_{\mathrm{C}}$ at $c a .320^{\circ} \mathrm{C}$ (Butler, 1992), and is very common in granites (e.g. Jover et al., 1989); however, the monoclinic pyrrhotite is chemically stable up to its Curie point (Dekkers, 1989), which cannot explain the disappearance of the inflection in the cooling cycling. The presence of maghemite in the analyzed samples, may be due to the oxidation of magnetite with increased furnace temperatures and the presence of oxygen in the system (Evans and Heller, 2003). Maghemite is normally destroyed before $350^{\circ} \mathrm{C}$, which could explain the inflection around $300^{\circ} \mathrm{C}$ in the heating curves and its absence in the cooling cycle. For that reason, maghemite is probably the magnetic mineral responsible for the inflection at $320^{\circ} \mathrm{C}$.

The thermomagnetic behavior of other Variscan granites is quite similar to the LOP. With the exception of the Lavadores-Madalena Pluton, the thermomagnetic curves show a slight drop before $580^{\circ} \mathrm{C}$, indicating a small quantity of magnetic minerals. The $K_{t}$ drops around $570^{\circ} \mathrm{C}$ and $565^{\circ} \mathrm{C}$ in the Vila Pouca de Aguiar Pluton (Fig. 10A) and Peneda-Gerês Pluton (Fig. 10B) samples, respectively. These values indicate the presence of Ti-poor magnetite, although Ti content in the sample from Peneda-Gerês Pluton is slightly higher (lower $\mathrm{T}_{\mathrm{c}}$ ) than the Vila Pouca de Aguiar Pluton. Regarding the Lavadores-Madalena Pluton experiments, the well-marked drop at $580^{\circ} \mathrm{C}$ demonstrates the presence of magnetite and the inflection at $300^{\circ} \mathrm{C}$ in the heating curve suggests the presence of maghemite in the Lavadores (Fig. 10C) and Madalena (Fig. 10D) granites. All $K_{t} v s$ T curves also revealed the presence of hematite.

\section{FINAL REMARKS AND CONCLUSIONS}

The magnetic mineralogy studies in the Portuguese posttectonic Variscan granites allowed to conclude that these are ilmenite- and magnetite-type-granites. Thermomagnetic curves are quite similar and show the presence of magnetite/ Ti-poor magnetite and hematite in all the plutons, though in different proportions. When the magnetite content is compared, a sequence can be established: Lavadores- 
Madalena $>$ Lamas de Olo $>$ Peneda-Gerês $>$ Vila Pouca de Aguiar. The presence of magnetite as accessory mineral allowed inferring the generation depth of magmas.

Previous studies in the LOP granites, demonstrated the co-occurrence of ferromagnetic and paramagnetic behavior in the pluton (Cruz et al., 2016). Alteration associated with the circulation of post-magmatic fluids, could explain the presence of other oxides such as Ti-poor magnetite and hematite in the granites.

The complexity of the magnetic mineralogy is not recognized in the magnetic susceptibility measurements, because this parameter only expresses the combined magnetic behavior of all minerals. For that reason, other methodologies (e.g. IRM, thermomagnetic curves, and frequency-dependent susceptibility) should be performed to identify magnetic minerals and their complex magnetic behaviors.

In the Vila Pouca de Aguiar Pluton, the magnetic mineralogy is simpler when compared with other plutons. Studies carried out in the Peneda-Gerês and LavadoresMadalena plutons pointed to a complex mineralogy, with the presence of both magnetite and ilmenite mineralogy in their granites.

With the exception of the Vila Pouca de Aguiar Pluton (where mineralizations have not yet been observed), the Variscan granites have associated mineralizations. The LOP has $\mathrm{W}(\mathrm{Mo})$ mineralizations associated with the $\mathrm{AC}$ and LO granites (Helal, 1992; Pereira, 1989); the Peneda-Gerês Pluton has W (Sn-Mo-Bi) mineralizations associated with their granites (Cottard, 1979; Cheilletz and Giuliani, 1982; Noronha, 1984), and in the Lavadores-Madalena Pluton, W (Mo) local occurrences have been described associated with the Madalena granite (Teixeira and Perdigão, 1962).

The Lamas de Olo, Peneda-Gerês and LavadoresMadalena plutons are all post-tectonic and composed of several granites of complex magnetic mineralogy, with magnetite/Ti-poor magnetite and ilmenite. Then we conclude that the presence of ilmenite- and magnetite-type in the same pluton, results from complex redox reactions, that occurs during the ascend and granite emplacement. The presence of magnetite pointing to a deep magma origin and oxidizing conditions in the magma chamber. This is an important metallogenic indicator of the $\mathrm{W}$ (Mo) mineralizations associated with post-tectonic biotite granites. Thus, the magnetic mineralogy can be a useful pathfinder for the W (Mo) mineralization exploration in the Iberian Peninsula.

The measurement of magnetic susceptibility is an unexpensive and rapid technique that can be used to characterize the magnetic behavior. The presence of magnetite and/or ilmenite allows to infer the redox condition of the granitic magma and to assess the metallogenic potential. However, the low field magnetic susceptibility measurements have some limitations when complex magnetic mineralogy is present, and for that reason, other magnetic studies should be performed.

\section{ACKNOWLEDGMENTS}

The first author was financially supported by SFRH/ BD/109693/2015 (Fundação para a Ciência e Tecnologia Portugal). The authors acknowledge funding from COMPETE 2020 through the ICT (Institute of Earth Sciences) project (UID/GEO/04683/2013) with POCI-01-0145 referenceFEDER-007690 and from ESMIMET, an INTERREG SpainPortugal POCTEP project. The authors also thank Philippe Olivier and Sonia Rousse for the thermomagnetic measurements carried out in Toulouse and their helpful comments and explanations during the advanced training in the Université de Toulouse III - Paul Sabatier. Acknowledgments are given to Alexandra Guedes for the follow-up and explanations given during the micro-Raman analyses. We thank Eric Font for the helpful guidance in paleomagnetism and explanations during the IRM and KfD\% analysis carried out in the Instituto Dom Luís facilities. The authors are grateful to Emilio L. Pueyo and another anonymous referee whose comments greatly helped to improve the manuscript.

\section{REFERENCES}

Abrajevitch, A., Kodama, K., 2011. Diagenetic sensitivity of paleoenvironmental proxies: A rock magnetic study of Australian continental margin sediments. Geochemistry, geophysics, geosystems, 12, Q05Z24.

Almeida, A., Leterrier, J., Noronha, F,, Bertrand, J.M, 1998. $\mathrm{U}-\mathrm{Pb}$ zircon and monazite geochronology of the Hercynian two mica granite composite pluton of Cabeceiras de Basto (Northern Portugal). Comptes Rendus de l'Académie des Sciences (Paris), 326, 779-785.

Antunes, I.M.H.R., Neiva, A.M.R., Silva, M.M.V.G., Corfu, F, 2008. Geochemistry of S-type granitic rocks from the reversely zoned Castelo Branco pluton (central Portugal). Lithos, 103, 445-465.

Aranguren, A., Tubia, J., Bouchez, J.L., Vigneresse, J.L., 1996. The Guitiriz granite, Variscan belt of northern Spain: extensioncontrolled emplacement of magma during tectonic escape. Earth and Planetary Science Letters, 139(1-2), 165-176.

Bouchez, J.L., 1997. Granite is never isotropic: an introduction to AMS studies of granitic rocks. In: Bouchez, J.L., Hutton, D.H.W., Stephens, W.E. (eds.). Granite: From Segregation of Melt to Emplacement Fabrics. Dordrecht, Kluwer Academic Publishers, 95-112. 
Bouchez, J.L., 2000. Magnetic susceptibility anisotropy and fabrics in granites. Comptes Rendus de l'Académie des Sciences de la Terre et des planets. Earth and Planetary Science, 330(1), 1-14.

Butler, R.F., 1992. Paleomagnetism: magnetic domains to geologic terranes. Blackwell Scientific Publications, 319pp.

Castiñeiras, P., Villaseca, C., Barbero, L., Martín Romera, C., 2008. SHRIMP U-Pb zircon dating of anatexis in high-grade migmatite complexes of Central Spain: implications in the Hercynian evolution of Central Iberia. International Journal of Earth Sciences, 97, 35-50.

Chadima, M., Jelinek, V., 2009. Anisoft 4.2: anisotropy data browser for windows. Advanced Geoscience Instruments Company (AGICO), Incorporated, Brno.

Chappell, B.W., White, A.J.R., 1974. Two contrasting granite types. Pacific Geology, 8, 173-174.

Cheilletz, A., Giuliani, G., 1982. Role de la Deformation du Granite dans la Genese des Episyenites Feldspathiques des Massifs de Lovios-Geres (Galice) et des Zaer (Maroc Central). Mineralium Deposita, 17(3), 387-400.

Cottard, F, 1979. Pétrologie structurale et métallogénie du Complexe Granitique de Lovios Geres. Le modèle de mise en place de la mine de Las Sombras (Sn-W-Mo-Bi) (Sud Galice Espagne). PhD Thesis. France, Universite de Nancy I, 243pp.

Cruz, C., Sant'Ovaia, H., Noronha, F., 2016. Magnetic susceptibility and $\delta^{18} \mathrm{O}$ characterization of Variscan granites related to W-(Mo) and Sn-(W) mineralizations: Lamas de Olo Pluton case study. Comunicações Geológicas, 103(1), 143-174.

Dallmeyer, R.D., Martínez Catalán, J.R., Arenas, R., Gil Ibarguchi, J.I., Gutiérrez Alonso, G., Farias, P., Aller, J., Bastida, F., 1997. Diachronous Variscan tectonothermal activity in the NW Iberian Massif: evidence from ${ }^{40} \mathrm{Ar} /{ }^{39} \mathrm{Ar}$ dating of regional fabrics. Tectonophysics, 277, 307-337.

Dearing, J.A., Dann, R.J.L., Hay, K., Lees, J.A., Loveland, P.J., Maher, B.A., O’Grady, K., 1996. Frequency-dependent susceptibility measurements of environmental materials. Geophysics Journal International,124, 228-240.

Dekkers, M.J., 1989. Magnetic properties of natural pyrrhotite. II. High- and low-temperature behaviour of Jrs and TRM as function of grain size. Physics of the Earth and Planetary Interiors, 57, 266-283.

Dias, G., Leterrier, J., Mendes, A., Simões, P., Bertrand, J.M., 1998. $\mathrm{U}-\mathrm{Pb}$ zircon and monazite geochronology of syn- to posttectonic Hercynian granitoids from the Central Iberian Zone (Northern Portugal). Lithos, 45, 349-369.

Dias, G., Noronha, F, Almeida, A., Simões, P.P., Martins, H.C.B., Ferreira, N., 2010. Geocronologia e petrogénese do plutonismo tardi-Varisco (NW de Portugal): síntese e inferências sobre o processo de acreção e reciclagem crustal na Zona CentroIbérica. In: Cotelo Neiva, J.M., Ribeiro, A., Victor, M., Noronha, F, Ramalho, M. (eds.). Geologia Clássica, Volume I - Ciências Geológicas: Ensino, Investigação e sua História. Geologia Clássica, Lisboa, Escolar Editora, 143-160.

Díez Fernández, R., Arenas, R., Pereira, M.F., Sánchez Martínez, S., Albert, R., Martín Parra, L.M., Rubio Pascual, FJ., Matas, J., 2016. Tectonic evolution of Variscan Iberia: gondwana-
Laurussia collision revisited. Earth Science Reviewer, 162, 269-292.

Dunlop, D.J., Özdemir, Ö., 1997. Rock magnetism: fundamentals and frontiers. Cambridge, Cambridge University Press, 573pp.

Ellwood, B.B., Wenner, D.B., 1981. Correlation of magnetic susceptibility with $18 \mathrm{O} / 16 \mathrm{O}$ data in late orogenic granites of the southern Appalachian Piedmont. Earth Planetary Science Letters, 54, 200-202.

Evans, M.E., Heller, F., 2003. Environmental Magnetism: Principles and Applications of Enviromagnetics. San Diego (California), Academic Press, 304pp.

Farias, P., Gallastegui, G., González Lodeiro, L., Marquínez, J., Martín Parra, L.M., Martínez Catalán, J.R., Pablo Maciá, J.G., Rodríguez Fernández, L.R., 1987. Aportaciones al conocimiento de la litoestratigrafia y estructura de Galicia Central. IX Reunião sobre a geologia do oeste peninsular, Museu e Laboratório Mineralógico e Geológico da Faculdade de Ciências da Universidade do Porto, 1 (Memórias), 411-431.

Fernandes, S., Gomes, M., Teixeira, R., Corfu, F., 2013. Geochemistry of biotite granites from the Lamas de Olo Pluton, northern Portugal. Geophysical Research Abstracts, EGU General Assembly, 15, 1pp.

Ferreira, N., Iglesias, M., Noronha, F., Pereira, E., Ribeiro, A., Ribeiro, M.L., 1987. Granitóides da Zona Centro Ibérica e seu enquadramento geodinâmico. In: Bea, F, Carnicero, A., Gonzalo, J.C., López Plaza, M., Rodriguez Alonso, M.D. (eds.). Geologia de los granitoides y rocas asociadas del Macizo Hespérico. Madrid, Rueda, 37-51.

Font, E., Ernesto, M., Silva, P.F,, Correia, P.B., Nascimento, M.A.L., 2009. Palaeomagnetism, rock magnetism and AMS of the Cabo Magmatic Province, NE Brazil, and the opening of South Atlantic. Geophysical Journal International, 179, 905-922.

Font, E., Veiga-Pires, C., Pozo, M., Carvalho, C., Neto, A.C.S., Camps, P., Fabre, S., Mirão, J., 2014. Magnetic fingerprint of southern Portuguese speleothems and implications for paleomagnetism and environmental magnetism. Journal of Geophysical Research Solid Earth, 119, 7993-8020.

Franke, W., 1989. Variscan plate tectonics in Central Europe - current ideas and open questions. Tectonophysics, 169, 221-228.

Gutiérrez-Alonso, G., Johnston, S.T., Weil, A.B., Pastor-Galán, D., Fernández-Suárez, J., 2012. Buckling an orogen: The Cantabrian Orocline. Geological Society of America Today, 22(7), 4-9.

Helal, B., 1992. Granitoïdes, granites à métaux rares et hydrothermalisme associe: géologie, minéralogie et géochimie de plusieurs suites tardi-hercyniennes (Nord du Portugal). Ph.D. Thesis. France, Ecole Nacionale Superieure des Mines de Saint-Etienne, 508pp.

Ishihara, S., 1977. The Magnetite-series and Ilmenite-series Granitic Rocks. Mining Geology, 27, 292-305.

Ishihara, S., Lee, D.S., Kim, S.Y., 1981. Comparative study of Mesozoic granitoids and related W-Mo mineralization in Southern Korea and Southwestern Japan. Mining Geology, 31(4), 311-320. 
Jover, O., Rochette, P., Lorand, J.P., Maeder, M., Bouchez, J.L., 1989. Magnetic mineralogy of some granites from the French Massif Central: origin of their low-field susceptibility. Physics of the Earth and Planetary Interiors, 55, 79-92.

Julivert, M., Fontboté, J.M., Ribeiro, A., Conde, L., 1974. Mapa tectónico de la península Ibérica y Baleares a escala 1:1.000.000 y memoria explicativa. Instituto Geologico y Mineiro de España, 113pp.

Kroner, U., Romer, R.L., 2013. Two plates - many subduction zones: The Variscan orogeny reconsidered.Gondwana Research, 24, 298-329.

Kruiver, P., Dekkers, M., Heslop, D., 2001. Quantification of magnetic coercivity components by the analysis of acquisition curves of isothermal remanent magnetisation. Earth and Planetary Science Letters, 189(3-4), 269-276.

Kumar, S., 2010. Magnetite and ilmenite series granitoids of Ladakh batholith, Northwest Indian Himalaya: implications on redox conditions of subduction zone magmatism. Current Science, 99(9), 1260-1264.

Lagoeiro, L.E., 1998. Transformation of magnetite to hematite and its influence on the dissolution of iron oxide minerals. Journal of Metamorphic Geology, 16, 415-423.

Marques, FO., Mateus, A., Tassinari, C., 2002. The Late-Variscan fault network in central-northern Portugal (NW Iberia): a reevaluation. Tectonophysics, 359(3-4), 255-270.

Martínez Catalán, J.R., Rubio Pascual, FJ., Díez Montes, A., Díez Fernández, R., Gómez Barreiro, J., Dias da Silva, Í., González Clavijo, E., Ayarza, P., Alcock, J.E., 2014. The late Variscan HT/LP metamorphic event in NW and Central Iberia: relationships to crustal thickening, extension, orocline development and crustal evolution. London, The Geological Society, 405 (Special Publications), 225-247.

Martins, H.C.B., Noronha, F, 2006. Late variscan granite pluton of Vila Pouca de Aguiar (Northern Portugal): an example of low ${ }^{87} \mathrm{Sr} /{ }^{86} \mathrm{Sr}$ felsic granites. Goldschmidt Conference Abstracts, 395.

Martins, H.C.B., Sant'Ovaia, H., Noronha, F, 2009. Genesis and emplacement of felsic Variscan plutons within a deep crustal lineation, the Penacova-Régua-Verín fault: An integrated geophysics and geochemical study (NW Iberian Peninsula). Lithos, 111, 142-155.

Martins, H.C.B., Sant'Ovaia, H., Abreu, J., Oliveira, M., Noronha, F, 2011. Emplacement of Lavadores granite (NW Portugal): $\mathrm{U} / \mathrm{Pb}$ and AMS results. Comptes Rendus Geocience, 343, 387-396.

Mateus, A., Noronha, F., 2010. Sistemas mineralizantes epigenéticos na Zona Centro-Ibérica; expressão da estruturação orogénica Meso- a Tardi-Varisca. In: Cotelo Neiva, J.M., Ribeiro, A., Victor, M., Noronha, F., Ramalho, M. (eds.). Geologia Clássica, Volume II - Ciências Geológicas: Ensino, Investigação e sua História. Geologia Aplicada, Lisboa, Escolar Editora, 143-160.

Maulana, A., Watanabe, K., Imai, A., Yonezu, K., 2013. Origin of magnetite- and ilmentite-series granitic rocks in Sulawesi, Indonesia: magma genesis and regional metallogenic constrains. Earth and Planetary Sciences, 6, 50-57.
Maxbauer, D.P., Feinberg, J.M., Fox, D.L., 2016. MAX UnMix: A web application for unmixing magnetic coercivity distributions. Computers \& Geosciences, 95, 140-145.

Mendes, A.C., Dias, G., 2004. Mantle-like Sr-Nd isotope composition of Fe-K subalkaline granites: the Peneda-Gerês Variscan massif (NW Iberian Peninsula). Terra Nova, 16, 109-115.

Nédélec, A., Trindade, R., Peschler, A., Archanjo, C., Macouin, M., Poitrasson, F., Bouchez, J.L., 2015. Hydrothermally-induced changes in mineralogy and magnetic properties of oxidized A-type granites. Lithos, 212(215), 145-157.

Noronha, F., Ramos, J.M.F, Rebelo, J., Ribeiro, A., Ribeiro, M.L., 1981. Essai de corrélation des phases de déformation hercyniennes dans le NW de la péninsule Ibérique. Leidse Geologische Mededelingen, 52(1), 87-91.

Noronha, F, 1984. Mineralizações espacial e geneticamente associadas ao maciço granítico da Serra do Gerês. Cuadernos do Laboratorio Xeolóxico de Laxe, 7, 87-99.

Noronha, F, Ferreira, N., Marques De Sá, C., 2006. Rochas granitóides: caracterização petrológica e geoquímica. In: Pereira, E. (coord.). Carta Geológica de Portugal. Notícia explicativa da folha 2, Lisboa, Instituto Geológoco Mineiro (IGM)/Instituto Nacional de Engenharia, Tecnologia e Inovação (INETI), 49-68.

Noronha, F, Ribeiro, M.A., Almeida, A., Dória, A., Guedes, A., Lima, A., Martins, H.C.B., Sant'Ovaia, H., Nogueira, P., Martins, T., Ramos, R., Vieira, R., 2013. Jazigos filonianos hidrotermais e aplitopegmatíticos espacialmente associados a granitos (norte de Portugal). In: Dias, R., Araújo, A., Terrinha, P., Kullberg, J.C. (eds.). Geologia de Portugal. Lisboa, Escolar Editora, Vol. I, 403-438.

Noronha, F, 2017. Fluids and Variscan metallogenesis in granite related systems in Portugal. Procedia Earth and Planetary Science, 17, 1-4.

Olivia-Urcia, B., Pueyo, E.L., 2012. Gradient of shortening and vertical-axis rotations in the Southern Pyrenees (Spain), insights from a synthesis of paleomagnetic data. Revista de la Sociedad Geológica de España, 20(1-2), 105-118.

Pastor-Galán, D., Gutierrez-Alonso, G., Zulauf, G., Zanella, F., 2012. Analogue modeling of lithospheric-scale orocline buckling: Constraints on the evolution of the Iberian-Armorican Arc. Geological Society of America Bulletin, 124, 1293-1309.

Pereira, E., Silva, N., Moreira, A., Ribeiro, A., 1987. Folha 10-A Celorico de Basto da Carta Geológica de Portugal na escala 1/50 000. Serviços Geológicos de Portugal.

Pereira, E., 1989. Carta Geológica de Portugal à escala 1:50 000, Notícia Explicativa da Folha 10-A (Celorico de Basto). Lisboa, Serviços Geológicos de Portugal, 53pp.

Pereira, M.F., Díez Fernández, R., Gama, C., Hofmann, M., Gärtner, A., Linnemann, U., 2018. S-type granite generation and emplacement during a regional switch from extensional to contractional deformation (Central Iberian Zone, Iberian autochthonous domain, Variscan Orogeny). International Journal of Earth Sciences, 107, 251-267.

Porquet, M., Pueyo, E.L., Róman-Berdiel, T., Olivier, P., Longares, L.A., Cuevas, J., Ramajo, J., Geokin3DPyr working group., 
2017. Anisotropy of magnetic susceptibility of the Pyrenean granites. Journal of Maps, 13(2), 438-448.

Ribeiro, A., Pereira, E., Dias, R., 1990. Structure of the Northwest of the Iberian Peninsula. In: Dallmeyer, D., Martinez Garcia, E. (eds.). Pre-Mesozoic Geology of Iberia. Berlin, Springer, 220-236.

Robertson, D., France, D., 1994, Discrimination of remanencecarrying minerals in mixtures, using isothermal remanent magnetization acquisition curves. Physics of Earth and Planetary Interiors, 82(3-4), 223-234.

Rochette, P., 1987. Magnetic susceptibility of the rock matrix related to magnetic fabric studies. Journal of Structural Geology, 9(8), 1015-1020.

Román-Berdiel, T., Pueyo-Morer, E.L., Casas-Sainz, A.M., 1995. Granite emplacement during contemporary shortening and normal faulting: structural and magnetic study of the Veiga Massif (NW Spain). Journal of Structural Geology, 17(12), 1689-1706.

Sant'Ovaia, H., 1993. Características magnéticas dos granitóides biotíticos pós-tectónicos de Vila Pouca de Aguiar. Provas de Aptidão Pedagógica e Capacidade Científica. Universidade do Porto, unpublished, 130pp.

Sant'Ovaia, H., Bouchez, J.L., Noronha, F., Leblanc, D., Vigneresse, J.L., 2000. Composite-laccolith emplacement of the posttectonic Vila Pouca de Aguiar granite pluton (northern Portugal): a combined AMS and gravity study. Transactions of the Royal Society of Edinburgh Earth Sciences, 91, 123-137.

Sant'Ovaia, H., Martins, H.C.B., Lopes, J.C., Machado, J., Noronha, F, 2012. Correlation of magnetic susceptibility with $\delta^{18} \mathrm{O}$ data in magnetite- and ilmenite-type granites from Iberian massif. Mineralogical Magazine, 76(6), 23-25.

Sant'Ovaia, H., Martins, H.C.B., Noronha, F, 2013a. Oxidized and reduced Portuguese Variscan granites associated with W and Sn hydrothermal lode deposits: magnetic susceptibility results. Comunicações Geológicas, 100(1), 33-39.

Sant'Ovaia, H., Martins, H.C.B., Noronha, F., 2013b. Magnetic susceptibility and $\delta^{18} \mathrm{O}$ characterization of granites related with W, Sn, Mo and Bi (Au) hydrothermal vein deposits. Mineralogical Magazine, 77(5), 2130-2130.

Sant'Ovaia, H., Ribeiro, M.A., Martins, H.C.B., Ferrão, F, Gomes, C., Noronha, F, 2014. Estruturas e fabric magnético no maciço granítico de Lavadores-Madalena. Comunicações Geológicas, 101(1), 313-317.

Shaw, J., Johnston, S.T., Gutiérrez-Alonso, G., Weil, A.B., 2012. Oroclines of the Variscan orogen of Iberia: Paleocurrent analysis and paleogeographic implications. Earth and Planetary Science Letters, 329-330, 60-70.

Sheppard, S.M.F, 1977. Identification of the origin of ore forming solutions by the use of stable isotopes. London, Volcanic Processes in Ore Genesis. Institution of Mining and Metallurgy and Geological Society, 254pp.

Takagi, T., Tsukimura, M., 1997. Genesis of oxidized- and reduced-type granites. Economic Geology, 92, 81-86.

Tarling, D.H., Hrouda, F, 1993. The magnetic anisotropy of rocks. London, Chapman \& Hall, 217pp.

Teixeira, C., Perdigão, J., 1962. Folha 13-A Espinho da Carta Geológica de Portugal na escala 1/50 000. Serviços Geológicos de Portugal.

Teixeira, R.J.S., Neiva, A.M.R., Gomes, M.E.P., Corfu, F, Cuesta, A., Croudace, I.W., 2012. The role of fractional crystallization in the genesis of early syn-D3, tin-mineralized Variscan twomica granites from the Carrazeda de Ansiães area, northern Portugal. Lithos, 153, 177-191.

Thadeu, D., 1965. Carta Mineira de Portugal, Notícia explicativa. Lisboa, Serviços Geológicos de Portugal, 46pp.

Villaseca, C., Ruiz-Martínez, V.C., Pérez-Soba, C., 2017. Magnetic susceptibility of Variscan granite-types of the Spanish Central System and the redox state of magma. Geologica Acta, 15(4), 379-394.

Weil, A., Gutiérrez-Alonso, G., Johnston, S.T., Pastor-Galán, D., 2013. Kinematic constraints on buckling a lithospheric-scale orocline along the northern margin of Gondwana: a geologic synthesis. Tectonophysics, 582, 25-49.

\footnotetext{
Manuscript received March 2019;

revision accepted Desember 2019;

published Online March 2020.
} 